\title{
Small scale environmental variation modulates plant defence syndromes of understorey plants in deciduous forests of Europe
}

\author{
Pieter Sanczuk $^{1}$ (D) | Sanne Govaert ${ }^{1}$ (D) | Camille Meeussen ${ }^{1}$ (D) | Karen De Pauw ${ }^{1}$ (D) \\ Thomas Vanneste $^{1}$ (D) | Leen Depauw ${ }^{1}$ (D) | Xoaquín Moreira ${ }^{2}$ | Jonas Schoelynck ${ }^{3}$ (D) | \\ Marthe De Boevre $^{4}$ (D) | Sarah De Saeger ${ }^{4}$ (D) | Kurt Bollmann $^{5}$ (D) | Jörg Brunet ${ }^{6}$ (D) | \\ Sara A. O. Cousins ${ }^{7}$ (D) | Jan Plue ${ }^{7}$ (D) | Martin Diekmann ${ }^{8}$ (D) | Bente J. Graae ${ }^{9}$ (D) | \\ Per-Ola Hedwall ${ }^{6}$ (D) | Giovanni lacopetti ${ }^{10}$ (D) | Jonathan Lenoir ${ }^{11}$ (iD) \\ Anna Orczewska $^{12}$ (i) | Quentin Ponette ${ }^{13}$ (i) | Federico Selvi ${ }^{10}$ (D) | \\ Fabien Spicher $^{11}$ (D) | Pieter Vermeir ${ }^{14}$ | Kim Calders ${ }^{15}$ (D) | Hans Verbeeck ${ }^{15}$ (D) | \\ Kris Verheyen $^{1}$ (D) | Pieter Vangansbeke ${ }^{1}$ (D) | Pieter De Frenne ${ }^{1}$ (D)
}

${ }^{1}$ Forest \& Nature Lab, Ghent University, Gontrode-Melle, Belgium

${ }^{2}$ Biological Mission of Galicia (MBG-CSIC), Pontevedra, Galicia, Spain

${ }^{3}$ Ecosystem Management Research Group, Antwerp University, Wilrijk, Belgium

${ }^{4}$ Centre of Excellence in Mycotoxicology and Public Health, Ghent University, Ghent, Belgium

${ }^{5}$ Swiss Federal Institute for Forest, Snow and Landscape Research WSL, Birmensdorf, Switzerland

${ }^{6}$ Southern Swedish Forest Research Centre, Swedish University of Agricultural Sciences, Alnarp, Sweden

${ }^{7}$ Biogeography and Geomatics, Department of Physical Geography, Stockholm

University, Stockholm, Sweden

${ }^{8}$ Vegetation Ecology and Conservation Biology, Institute of Ecology, University of Bremen, Bremen, Germany

${ }^{9}$ Department of Biology, Norwegian University of Science and Technology, Trondheim, Norway

${ }^{10}$ Department of Agriculture, Food, Environment and Forestry, University of Firenze, Firenze, Italy

${ }^{11} U R$ «Ecologie et Dynamique des Systèmes Anthropisés» (EDYSAN, UMR7058 CNRS), Université de Picardie Jules Verne, Amiens, France

${ }^{12}$ Institute of Biology, Biotechnology and Environmental Protection, University of

\begin{abstract}
Aim: Variation in plant defence traits has been frequently assessed along largescale macroclimatic clines. In contrast, local-scale changes in the environment have recently been proposed to also modulate plant defence traits. Yet, the relative importance of drivers at both scales has never been tested. We aimed to quantify the relative importance of environmental drivers inherent to large and small spatial scales on the physical and chemical defence and tolerance to herbivory in understorey plant species of deciduous forests of Europe.

Location: Deciduous forests in Europe.

Time period: Present.

Major taxa studied: Forest understorey plants.

Methods: We sampled four typical ancient forest herbs (Anemone nemorosa, Oxalis acetosella, Deschampsia cespitosa, Milium effusum) along small and large spatial scale gradients (those driven by latitude, elevation, forest management and distance to the forest edge), and analysed a suite of nine constitutively expressed traits associated with overall resistance to herbivory, and their multivariate response to environmental clines.

Results: Although our study included a large gradient in macroclimate, we found variation in the local environment at small spatial scales (i.e. soil nutrient concentration and forest structural complexity) to be more important in predicting plant resistance to herbivory.
\end{abstract}


Silesia, Katowice, Poland

${ }^{13}$ Earth and Life Institute, Université catholique de Louvain, Louvain-La-Neuve, Belgium

${ }^{14}$ Laboratory for Chemical Analysis (LCA), Ghent University, Ghent, Belgium

${ }^{15}$ CAVElab - Computational and Applied Vegetation Ecology, Ghent University, Ghent, Belgium

\section{Correspondence}

Pieter Sanczuk, Forest \& Nature Lab, Ghent University, Geraardsbergsesteenweg 267, BE-9090 Gontrode-Melle, Belgium.

Email: Pieter.Sanczuk@UGent.be

\section{Funding information}

PS, CM, LD, PVG and PDF received funding from the European Research Council (ERC) under the European Union's Horizon 2020 research and innovation programme (ERC Starting Grant FORMICA 757833).

$S G$ received funding from the Research Foundation Flanders (FWO) (project $\mathrm{GOH} 1517 N$ ). KDP received funding from the Research Foundation Flanders (FWO ASP035-19 De Pauw). TV was funded by the Special Research Fund (BOF) from Ghent University (01N02817). XM was financially supported by a grant from the Spanish Ministry of Science, Innovation and Universities (RTI2018-099322-B-100) and the Ramón y Cajal Research Programme (RYC-2013-13230). HV received funding from the ERC for this research through the TREECLIMBERS project (ERC Grant 637643) and Belgian Science Policy Office (BELSPO) in the frame of the STEREO III Program (Project 3D-FOREST, Grant SR/02/355). $\mathrm{KV}$ received funding from the European Research Council (ERC) for funding this research through the PASTFORWARD project (ERC Consolidator Grant 614839).

Editor: Benjamin Blonder defence phenotypes. These findings highlight the importance of the local habitat structure and environmental conditions in modulating plant resistance to herbivory.

\section{KEYWORDS}

climate, forest microclimate, forest understorey, latitudinal gradient, plant defence syndrome, plant-herbivore interactions, resource availability hypothesis

\section{1 | INTRODUCTION}

Since the origin of the first groups of phytophagous insects in the early Mesozoic (c. $250 \mathrm{Ma}$ ), plants have evolved an impressive arsenal of defence mechanisms to minimize herbivory damage (Labandeira, 1998). Although some plant species evolved complex physical structures (e.g. thorns and spines), most species are typically armed with a suite of subtle physical (e.g. trichomes) and chemical (e.g. phenolic compounds, alkaloids) defence traits that potentially increase the individuals' fitness under herbivore pressure (Agrawal, 2007; Agrawal \& Fishbein, 2006; Duffey \& Stout, 1996; Moles et al., 2013). Most traits, however, are not exclusively related to plant defence, but also play an adaptive role in the plant's resilience to abiotic stresses such as extreme heat events and deep shade (Moles et al., 2013). Leaf trichomes, for example, can act as a mechanical barrier for herbivores (Abdala-Roberts, Moreira, et al.,
2016; Haddad \& Hicks, 2000), but also reduce leaf evapotranspiration rates in arid conditions (Gonzáles et al., 2008; Woodman \& Fernandes, 1991). Such dual functional roles cause plant traits to be under multiple selective pressures from biotic (e.g. herbivory) and abiotic (e.g. climate) factors, and underpin the interactive nature of trait evolution along ecological gradients (e.g. Buckley et al., 2019; Galmán et al., 2018; Pellissier et al., 2016). This makes it extremely complex to elucidate global patterns of variation in plant resource allocation to defence against herbivores.

Nevertheless, geographic variation in plant investment in defence traits frequently follows changes in biotic and abiotic conditions (Dobzhansky, 1950; Moles, Bonser, et al., 2011; Moreira et al., 2014; Rasmann et al., 2014; Schemske et al., 2009). One of the most prominent gradients in biogeography is the increase in biotic interactions from the poles towards the equator, explained by higher temperatures, longer growing seasons and more stable 
climatic conditions that facilitate speciation and population growth (Coley \& Barone, 1996; De Frenne et al., 2013; Dobzhansky, 1950; Pennings et al., 2009; Schemske et al., 2009). As a result, plants native to lower latitudes usually experience a stronger predation pressure from a larger and more diverse herbivore community, which is believed to promote directional selection for increased investment in constitutive defence (Abdala-Roberts, Rassman et al., 2016; Coley \& Barone, 1996; Rasmann \& Agrawal, 2011; Rasmann et al., 2014; Schemske et al., 2009). However, to date, such a general pattern remains elusive (reviewed in Moles, Wallis, et al., 2011, but see Salazar \& Marquis, 2012). Indeed, studies comparing inter- or intraspecific resource allocation to constitutive defence along latitudinal gradients have found variable patterns of defence investment with increasing latitude (Abdala-Roberts, Moreira, et al., 2016; Kooyers et al., 2017; Loughnan \& Williams, 2019; Lynn \& Fridley, 2019; Moles, Wallis, et al., 2011; Moreira et al., 2015; Moreira, Castagneyrol, et al., 2018). Furthermore, based on the assumption that the intensity of herbivory decreases with elevation, many studies predicted that investment in defence traits will decline with increasing elevation (reviewed in Moreira, Petry, et al., 2018). Some studies indeed found that plants allocate more resources to defence at lower elevations (e.g. Pellissier et al., 2016), while a significant number of studies have shown opposite trends (e.g. Rasmann et al., 2014) or no clear trends related to elevation (e.g. Buckley et al., 2019).

Such contrasting patterns in response to latitude or elevation suggest that other processes are driving variation in plant defence traits, possibly because:

1. Variation in herbivore pressure itself is independent of latitude (Moles, Bonser, et al., 2011) and elevation (Abdala-Roberts, Rassman et al., 2016; Moreira, Petry, et al., 2018), or insufficient to causally explain variation in defence traits (Buckley et al., 2019; Galmán et al., 2018; Loughnan \& Williams, 2019; Moles et al., 2013; Pellissier et al., 2016; Rasmann et al., 2014).

2. Traits related to plant defence can also play a vital role in other plant functions that experience a strong selection pressure in response to environmental gradients that are unrelated - or show opposite trends - to clines in herbivore pressure across latitude or elevation (i.e. conflicting ecological drivers, Abdala-Roberts, Rassman et al., 2016; Agrawal, 2019).

3. Plant functional traits not primarily related to defence can significantly contribute to the plant defence phenotype (Agrawal \& Fishbein, 2006; Carmona et al., 2011). For example, specific leaf area (SLA), foliar nitrogen $(\mathrm{N})$ and phosphorus $(\mathrm{P})$ concentrations are important plant functional traits for resource acquisition and nutrient cycling, but also contribute to the overall plant's attractiveness and tolerance to herbivory (i.e. the ability of plants to compensate for tissue loss), and sometimes constitute a better predictor of herbivore damage compared to classical defence traits (Agrawal \& Weber, 2015; Carmona et al., 2011; Kurokawa et al., 2010; Loranger et al., 2012; Reese et al., 2016).

4. The spatial scale of sampling along latitudinal or elevational gradients (partly) mismatches the spatial scale of evolutionary processes that are postulated to drive variation in defence traits (Gaston, 2000). Forest edge-to-core transects, for example, are characterized by strong abiotic clines in temperature, humidity, light and soil nutrient availability (De Frenne et al., 2019; Meeussen et al., 2020; Murcia, 1995; Remy et al., 2016), as well as biotic clines in the floral, arthropod and gastropod community composition over less than 100 m (De Smedt et al., 2019; Govaert et al., 2020; Lantman et al., 2019).

Although all these factors determine plant resource allocation to defence or tolerance to herbivory (e.g. Coley et al., 1985; de Vries et al., 2019; Janzen, 1970; Lynn \& Fridley, 2019; Moreira et al., 2016), the importance of such drivers at small spatial scales, relative to macroclimatic drivers, remains largely understudied.

Overall, there is a need for a research framework that: (a) integrates biotic and abiotic correlates of latitude and elevation (Kooyers et al., 2017), (b) accurately describes local conditions experienced by plants and herbivores at small (i.e. population level) and large (i.e. across species' distribution ranges) spatial scales, and (c) ultimately considers the multivariate nature of a plant's defence phenotype. To our knowledge, however, such a multidimensional approach has not been conducted yet.

Here we studied the relative effects of large-scale macroclimate gradients (i.e. changes in the environment across latitudes and elevations) versus small-scale forest microclimate gradients (i.e. changes in the environment along forest edge-to-core transects and due to forest management intensity). We assessed constitutively expressed physical and chemical traits associated with defence or tolerance to herbivory in four understorey plants species growing in deciduous forests of Europe. Given the regulating role of the overstorey on understorey biotic and abiotic conditions and resources, we hypothesize that small-scale changes in the environment related to forest microclimates play a major role in modulating plant defence phenotypes.

\section{MATERIAL AND METHODS}

\section{1 | Study species}

To study spatial patterns and environmental drivers of forest understorey plant species investment in constitutive defence and tolerance to herbivores, four species (two graminoids and two dicots) were selected based on their broad latitudinal distributions (Figure 1), common occurrence in European deciduous woodlands, phenology and alternative defence strategies.

Anemone nemorosa L. (Ranunculaceae) is a spring-flowering rhizome geophyte commonly observed in ancient and undisturbed Eurasian deciduous forests and woodlands (De Frenne et al., 2011; Verheyen et al., 2003). Its latitudinal range stretches from northern Spain to northern Scandinavia (Hultén \& Fries, 1986).

Oxalis acetosella L. (Oxalidaceae) is a low-growing rhizomatous perennial forest herb frequently associated with ancient deciduous 
Anemone nemorosa

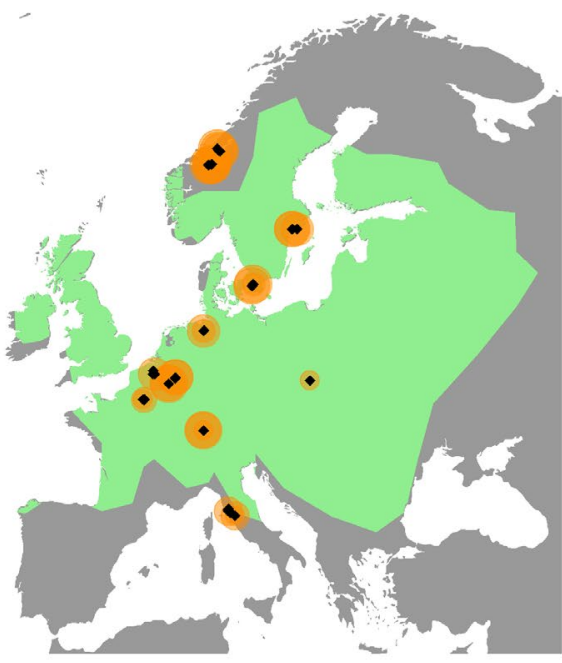

Deschampsia cespitosa

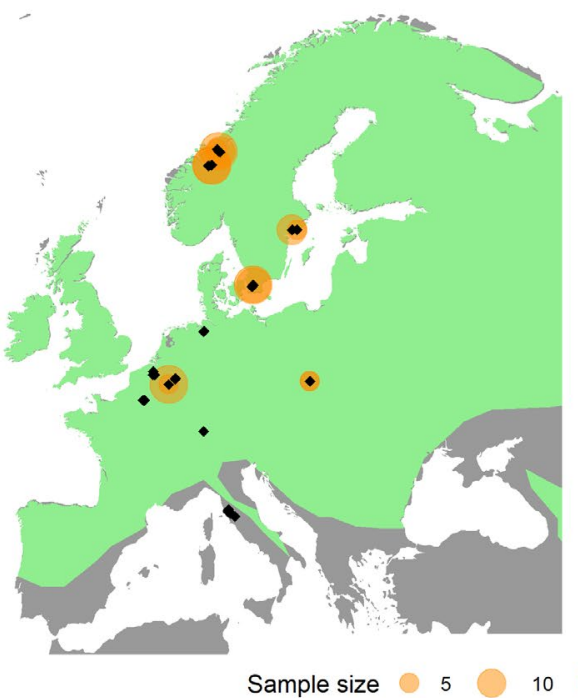

Oxalis acetosella

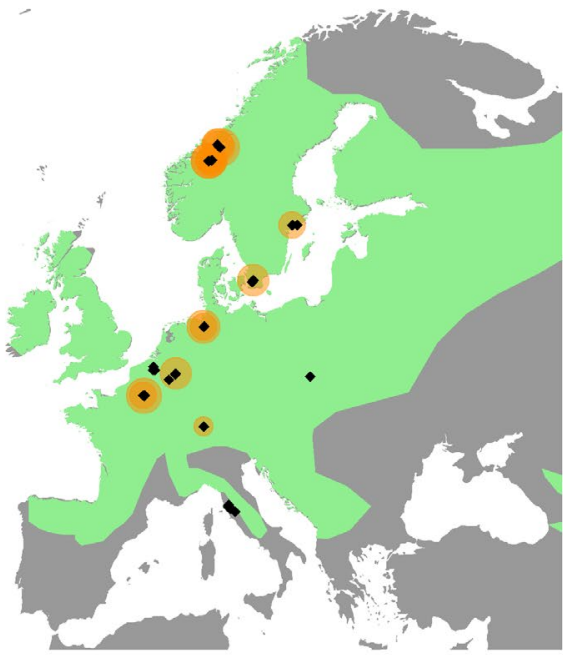

Milium effusum

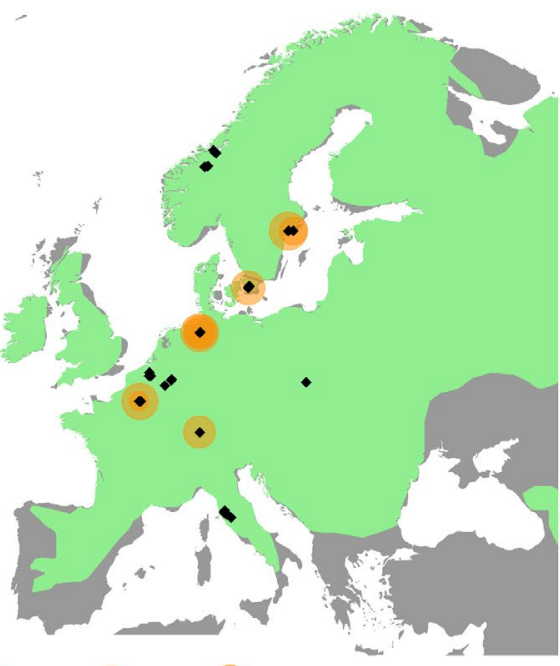

FIGURE 1 Latitudinal sample distribution relative to the species' specific distribution range (green area) for each study species (source: Hultén \& Fries, 1986). Fifteen geographic sites were sampled (black diamonds). The size of the orange circles represents the sample size in each geographic site

forests. Within Europe, its distribution range stretches from central Spain to northern Scandinavia (Hultén \& Fries, 1986) where it grows on drained to wet soils (Packham, 1978).

Deschampsia cespitosa (L.) P.Beauv. (Poaceae) is a common perennial grass species native to marshes, meadows and woodlands with nutrient-poor and drained to wet soils. Within Europe, its range spans from central Spain to northern Scandinavia (Hultén \& Fries, 1986).

Milium effusum L. (Poaceae) is a perennial grass species associated with temperate deciduous woodlands, growing on soils with an intermediate level of soil fertility and pH (De Frenne et al., 2017). Its distribution range stretches from the Mediterranean area to northern Scandinavia (Hultén \& Fries, 1986).

\section{2 | Study design}

We sampled 225 forest plots $(3 \mathrm{~m} \times 3 \mathrm{~m}$ ) distributed over 45 south orientated forest edge-to-core transects (five plots per transect) placed along a gradient of more than 20 latitudinal degrees within Europe (latitudinal range: $42.5-63.5^{\circ} \mathrm{N}$; c. $2,300 \mathrm{~km}$; mean annual temperature range: $2.4-12.6^{\circ} \mathrm{C}$ ). The forest transects were distributed across nine geographic regions (central Norway, central Sweden, southern Sweden, northern Germany, southern Poland, Belgium, northern France, northern Switzerland and central Italy). Three additional elevation gradients were investigated in central Norway, Belgium and central Italy (low, medium and high, elevational range: 9-780 $\mathrm{m}$ a.s.l.) to capture a major part of the macroclimatic variation in European deciduous forests. As such, this study covered 15 geographic sites (nine lowland, three intermediate and three high elevation sites).

Within each of the 15 geographic sites, three forest stands with a contrasting management history were selected to represent alternative types of forest structure. The most structurally complex forest type typically had a well-developed shrub layer and a high basal area (proxy for tree stocking rate and biomass). These forests were not managed during the last 10 years and generally not thinned for $>30$ years. This type of forest will be referred to as dense forest type. 
In contrast, the most structurally simple forest type was characterized by a high canopy openness and absence of a well-developed shrub layer due to recent thinning activities (generally 1 to 4 years prior to sampling). This type of forest will be referred to as open forest type. Forests with an intermediate management regime and structure will be referred to as intermediate forest type.

All the selected forest stands covered an area larger than 4 ha and were mostly dominated by oaks (Quercus robur, Quercus petraea, Quercus cerris). Other common deciduous tree species such as Fagus sylvatica, Betula sp., Populus sp., Ulmus glabra, Alnus incana and Carpinus betulus were allowed as subdominant species in the canopy layer. All forest stands are ancient, that is, they were continuously forested land since at least the earliest reliable land-use maps, generally $150-300$ years prior to sampling.

Forest edge-to-core gradients were studied by sampling five $3 \mathrm{~m} \times 3 \mathrm{~m}$ plots placed along south orientated transects perpendicular to the forest edge. The forest edge was defined as the outer edge of the forest stand that meets a matrix of agricultural land, usually created by ancient deforestation. As the southern edge of the first plot on the transect was set as the edge of the forest per se, the centre of this plot was positioned at $1.5 \mathrm{~m}$ from the forest edge. The centres of the remaining plots were positioned at 4.5, 12.5, 36.5 and $99.5 \mathrm{~m}$ from the defined forest edge. As such, a total of 225 forest plots (15 geographic sites $\times 3$ forest types $\times 5$ plots) were sampled.

More details can be found in Govaert et al. (2020) and Meeussen et al. (2020) as we rely on the same study design.

\section{3 | Plant material collection}

Plant material was collected for all four study species occurring in each of the 225 plots. Sampling of plant material was conducted during early summer 2018, starting at the southernmost plots to account for differences in phenological stages across latitudes [see Govaert et al. (2020) for details].

Leaf samples and aboveground biomass were taken from five mature individuals of the four studied species (if present in the plot). Given the high degree of vegetative reproduction in many understorey plants, if possible, sampling was spaced more than $1 \mathrm{~m}$ apart to avoid sampling clones. All collected leaves had minor or no herbivore damage to be able to study patterns in constitutively expressed defence traits (i.e. not induced in response to herbivore attack). All leaf and biomass samples were weighed and ground after drying to constant weight at $40^{\circ} \mathrm{C}$ for $48 \mathrm{hr}$. The latitudinal sample distribution ranged between $88 \%$ (Anemone nemorosa) and 34\% (Milium effusum) of the latitudinal species distribution (see Figure 1 and Supporting Information Figure S2 and Table S1 for details on species-specific sample distribution across the 225 plots).

\section{4 | Plant traits}

Given that plants rely on multiple traits to cope with herbivory (Agrawal \& Fishbein, 2006), we quantified plant defence and tolerance in a pluralistic manner, that is, considering a suite of 10 physical and chemical traits simultaneously.

Two physical traits were assessed at the level of the individual resulting in 494 samples for $A$. nemorosa, 153 samples for O. acetosella, 152 samples for $D$. cespitosa and 89 samples for M. effusum.

Trichome density was estimated for all leaf samples of $A$. nemorosa and $O$. acetosella on the leaf surface, and for M. effusum on the leaf margin. Deschampsia cespitosa has hook-shaped trichomes positioned on longitudinal ridges at the adaxial leaf side and leaf margins. For this species, trichome density was assessed by counting the number of trichomes on one of these adaxial ridges (not on leaf margins). Counts were performed on pictures taken with a digital microscope (DinoCapture 2.0, AnMo Electronics Corporation, Taiwan). All counted densities were expressed into standard units (per $\mathrm{cm}^{2}$ or per cm; see Supporting Information Figure S1 and Table S2 for details). Leaf trichomes can act as a mechanical barrier for herbivores (Gonzáles et al., 2008).

Specific leaf area (SLA, $\mathrm{mm}^{2} / \mathrm{mg}$ ) for each leaf was assessed by dividing leaf area $\left(\mathrm{mm}^{2}\right)$ by leaf dry weight $(\mathrm{mg})$. Leaf area was measured with a LiCor LI-3000C Area Meter (LI-COR Biosciences, Lincoln, Nebraska). SLA is an important functional trait for nutrient cycling, positively related to the capacity of the plant to compensate for tissue loss (Kurokawa et al., 2010) and negatively related to the leaf physical toughness (Iddles et al., 2003; Moles, Wallis, et al., 2011), an effective defence against herbivores (Descombes et al., 2019).

Eight chemical traits were analysed based on samples that were pooled at the plot level, resulting in 103 samples for $A$. nemorosa, 33 samples for $O$. acetosella, 33 samples for $D$. cespitosa and 19 samples for M. effusum.

Foliar carbon (C) and nitrogen ( $N$ ) concentrations (mg/g dry weight) were analysed for $50 \mathrm{mg}$ oven-dried samples by high temperature combustion at $1,150{ }^{\circ} \mathrm{C}$ using an elemental analyzer (Vario MACRO cube, Elementar, Langenselbold, Germany). Foliar $\mathrm{N}$ concentrations are positively related to herbivore consumption rates (Agrawal \& Weber, 2015) and provide a strong predictor for herbivore damage (Carmona et al., 2011).

Foliar $\mathrm{C}: \mathrm{N}$ ratios were calculated by dividing $\mathrm{C}$ by $\mathrm{N}$ concentrations. The foliar $\mathrm{C}: \mathrm{N}$ ratio is negatively related to the plant nutritional quality and generally negatively affects herbivory damage.

Foliar phosphorus $(P)$ and calcium (Ca), concentrations (mg/g dry weight) were obtained after digesting $100 \mathrm{mg}$ of the sample with

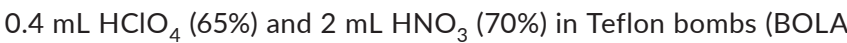
Digestion Vessels, Bohlender $\mathrm{GmbH}$, Grünsfeld, Germany) for $4 \mathrm{hr}$ at $140{ }^{\circ} \mathrm{C}$. Phosphorus was measured colorimetrically according to the malachite green procedure (Lajtha et al., 1999). Calcium was measured by atomic absorption spectrophotometry (AA240FS, Fast Sequential AAS, Agilent Technologies, Santa Clara, California). When included in biominerals such as calcium oxalate crystals, this deters herbivores (Ruiz et al., 2002).

Foliar $N$ : $P$ ratios were subsequently calculated by dividing $N$ by $\mathrm{P}$ concentrations. The foliar $\mathrm{N}: \mathrm{P}$ ratio is positively related to the palatability of the plant (Kurokawa et al., 2010). 
Total phenolic concentration ( $\mathrm{mg} / \mathrm{g}$ dry weight) was analysed as described by Moreira et al. (2014). Extractions were performed on $20 \mathrm{mg}$ ground and oven-dried $\left(45^{\circ} \mathrm{C}\right)$ plant material in a $70 \%$ methanol solution followed by sonification for $15 \mathrm{~min}$. The total phenolic concentration was subsequently analysed calorimetrically by the Folin-Ciocalteu method in a Biorad 650 microplate reader (Bio-Rad Laboratories, PA, Hercules, California) at 740 nm, using tannic acid as standard. Foliar phenolics are generally known as common herbivore feeding deterrents (Moreira et al., 2014).

Biogenic silica (BSi) concentration (mg/g dry weight) was determined following Demaster (1981): $25 \mathrm{mg}$ ground and oven-dried $\left(45^{\circ} \mathrm{C}\right.$ ) plant tissue was incubated in $25 \mathrm{~mL} 0.5 \mathrm{M} \mathrm{NaOH}$ at $80^{\circ} \mathrm{C}$ for $5 \mathrm{hr}$. The extracted and dissolved silica was then analysed colorimetrically on a segmented flow analyser (SAN++, Skalar, Breda, The Netherlands). High biogenic silica concentration increases leaf abrasiveness, and, therefore, deters herbivore feeding (Massey et al., 2007).

Ergot-alkaloid concentration was quantified in 13 samples of $D$. cespitosa and six samples of M. effusum. These samples were tested for a suite of 14 common ergot-alkaloids. The alkaloid concentration in all these samples, however, was below the detection limit and, therefore, not included in the data analyses. See Supporting Information Method S1 for more details.

These analytical measures provide a good proxy of the quantitative allocation to effective overall defence and tolerance for herbivores (Agrawal \& Weber, 2015; Carmona et al., 2011; Descombes et al., 2019; Gonzáles et al., 2008; Loranger et al., 2012; Massey et al., 2007; Moreira et al., 2014). It is important to note, however that sample sizes varied among species (Supporting Information Figure S2), which may have reduced the statistical power of the analyses for species with a lower sample size.

\section{5 | Environmental predictor variables}

We quantified the environment of each plot by assessing macroclimatic conditions, forest structure, understorey microclimatic conditions and soil characteristics.

Macroclimate among the 225 studied plots was quantified by high-resolution (c. $1 \mathrm{~km}^{2}$ ) climate data extracted from the CHELSA database (version 1.2, Karger et al., 2017; Supporting Information Figure $\mathrm{S} 4 \mathrm{a}, \mathrm{b})$. This database compiles high-resolution average monthly temperature and precipitation values for the period 1997-2013. We extracted the bioclimatic variables of mean annual temperature (BIO1), mean diurnal temperature range (BIO2), temperature seasonality (BIO4), maximum temperature of warmest month (BIO5), minimum temperature of the coldest month (BIO6), mean annual precipitation (BIO12), precipitation of the wettest month (BIO13), precipitation of the driest month (BIO14) and precipitation seasonality (BIO15).

Forest structure was quantitatively measured by means of single-scan position terrestrial laser scanning (TLS) using a RIEGL VZ400 (RIEGL Laser Measurement Systems GmbH, Horn, Austria) in the centre of each plot (Supporting Information Figure S6b). In detail, we used plant area index (PAI) estimates as proxies for forest structure. PAI is defined as half of the surface area of all above-ground vegetation matter per unit of horizontal ground surface area. The PAI is calculated as the integral of vertically resolved plant area per volume density (PAVD; $\mathrm{m}^{2} / \mathrm{m}^{3}$ ) profiles derived from TLS. As such, PAI is positively related to forest complexity and negatively related to the amount of light that reaches the forest floor. Applying TLS yields better results compared to conventional forest surveys or optical ground-based surveys, as this approach is more holistic, highly reproducible and insensitive to illumination conditions (Calders et al., 2018). Meeussen et al. (2020) provide a detailed description of the TLS methods.

Understorey microclimatic conditions can significantly differ from the overarching macroclimate and represent the conditions that are experienced by species living in the shade of trees (De Frenne et al., 2019). The magnitude of the offset between macroclimatic temperatures and temperatures below the canopy inherently couples to forest structure and distance to the forest edge. To quantify these offset values at the plot level, miniature temperature loggers (Lascar type EasyLog EL-USB-1, Lascar Electronics, Whiteparish, UK; accuracy at $-35-+80^{\circ} \mathrm{C}: \pm 0.5^{\circ} \mathrm{C}$ ) were installed exactly in the centre of all 225 plots at $1 \mathrm{~m}$ above the soil surface, covered by a radiation shield. Data loggers were installed at least 1 month prior to sampling (winter-spring 2018). Local air temperature was recorded at 1-hr intervals. For each miniature logger, we computed daily minimum (as the $5 \%$ percentile of the 24 daily measurements) and daily maximum (as the $95 \%$ percentile of the 24 daily measurements) air temperature values. Air temperatures outside the forest were recorded with the same type of miniature data loggers covered by a radiation shield and again installed at $1 \mathrm{~m}$ above the soil surface in each sampled geographic site (15 open sensors). All these data were used to quantify the magnitude of temperature offset during the growing season of the year of sampling (1 June 2018-30 September 2018). The offset values thus represent the magnitude of thermal buffering experienced by understorey species, and are, therefore, complementary to the average overstorey macroclimate data.

For each plot, we calculated the mean daily minimum and maximum temperature offset values ( $\mathrm{T}_{\text {OFFSET }}$ MIN and $\mathrm{T}_{\text {OFFSET }}$ MAX) by subtracting macroclimate minimum/maximum temperatures values from microclimate minimum/maximum temperatures values (Supporting Information

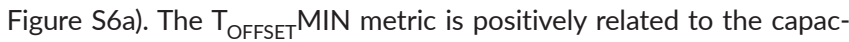
ity of the overstorey to buffer macroclimatic temperature minima. The $\mathrm{T}_{\mathrm{OFFSET}} \mathrm{MAX}$ metric is negatively related to the capacity of the overstorey to buffer macroclimatic temperature maxima.

Soil $\mathrm{pH}$ and element concentrations were analysed for pooled samples derived from five random mineral topsoil cores per plot (0-10 cm; diameter $30 \mathrm{~mm}$ ) (Supporting Information Figures S4c,d and S5). All soil samples were oven-dried at $40{ }^{\circ} \mathrm{C}$ for $48 \mathrm{hr}$ to constant weight, ground and sieved over a 2-mm mesh. The $\mathrm{pH}-\mathrm{H}_{2} \mathrm{O}$ method was used to assess soil $\mathrm{pH}$. We measured it by shaking a 1:5 ratio soil/ $\mathrm{H}_{2} \mathrm{O}$ mixture for $5 \mathrm{~min}$ at $300 \mathrm{rpm}$ and using a pH meter (Orion 920A, Thermo Scientific Orion, Waltham, 
Massachusetts). Soil $\mathrm{C}$ and $\mathrm{N}$ content was analysed by combusting the samples at $1,200{ }^{\circ} \mathrm{C}$ followed by measurements of the gases by a thermal conductivity detector in an elemental analyzer (Vario MACRO cube CNS, Elementar, Langenselbold, GermanyAQ24). Bioavailable phosphorus (Olsen P; Gilbert et al., 2009) was measured by extraction in $\mathrm{NaHCO}_{3}$ [according to ISO 11263:1994(E)] and colorimetric measurements were performed according to the malachite green procedure (Lajtha et al., 1999). Total Ca and $\mathrm{Mg}$ were measured by atomic absorption spectrophotometry (AA240FS, Fast Sequential AAS) after complete destruction of the soil samples with $\mathrm{HClO}_{4}(65 \%), \mathrm{HNO}_{3}(70 \%)$ and $\mathrm{H}_{2} \mathrm{SO}_{4}(98 \%)$ in Teflon bombs for $4 \mathrm{hr}$ at $150^{\circ} \mathrm{C}$.

Soil texture was analysed by sieving and sedimentation with a Robinson-Köhn pipette according to ISO 11277 (2009).

\section{6 | Data analyses}

In a first step, we explored the correlation structure among the nine herbivory resistance traits (trichome density, SLA, total phenolic concentration, $\mathrm{BSi}, \mathrm{Ca}, \mathrm{C}: \mathrm{N}$ ratio, $\mathrm{N}: \mathrm{P}$ ratio, $\mathrm{N}$ and $\mathrm{P}$ ) in each of the four studied species. To do so, we performed an independent principal component analysis (PCA) for each species using the R function PCA from the package FactoMineR (Lê et al., 2008). All traits were plotted against the principal components (PC) that maximally captured the variation in the data set (i.e. PC1 and PC2). The first PC axis was subsequently set as defence phenotype axis 1 (referred to as PC $1_{\text {DEFENCE }}$ ). The second PC axis was set as defence phenotype axis 2 (referred to as PC2 $2_{\text {DEFENCE }}$ ). For this analysis, physical defence traits were averaged at the plot level to match the resolution of the chemical defence data. All response variables were scaled to unit variance prior to the PCA. Missing values (across all species and traits, $1.94 \%$ missing, Supporting Information Table S1) were imputed with the $\mathrm{R}$ function imputePCA from the package missMDA (Josse \& Husson, 2016).

In a second step, PC1 $1_{\text {DEFENCE }}$ and PC2 $2_{\text {DEFENCE }}$, and the suite of nine traits were separately analysed using linear mixed-effect models (LMMs). To account for possible spatial autocorrelation (nested sampling design) in all models presented below, PC1 $1_{\text {DEFENCE }}$ and PC2 ${ }_{\text {DEFENCE, }}$ and all chemical plant traits (BSi, Ca, total phenolic concentration, $\mathrm{C}: \mathrm{N}$ ratio, $\mathrm{N}: \mathrm{P}$ ratio, $\mathrm{N}$ and $\mathrm{P}$ ) were modelled with the random effect term 'transect' nested within 'region' since theses samples were pooled at the plot level. All physical plant traits (trichome density and SLA) were modelled with the random effect term 'plot' nested within 'transect', nested within 'region'.

To make use of all the variation captured by the nine macroclimate and nine soil variables included in this study, we performed separate PCAs for macroclimate and soil variables. The first two macroclimate PCs explained $76 \%$ of the variation across the 225 plots (Supporting Information Figure S3a,c; Table S4a). The first

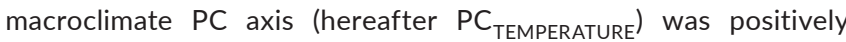
correlated to mean temperature, minimum temperature, maximum temperature and temperature range $(r>.78)$. The second macroclimate PC axis (hereafter PC PRECIPITATION $_{\text {) was positively correlated }}$ to precipitation seasonality $(r=.91)$ and negatively correlated to mean precipitation and minimum precipitation $(r<-.88)$. The first two soil PCs explained $63 \%$ of the variation across the 225 plots of this study (Supporting Information Figure S3b,d; Table S4b). The first soil $\mathrm{PC}$ axis (hereafter $\mathrm{PC}_{\mathrm{pH}}$ ) was positively correlated to soil $\mathrm{pH}$, soil $\mathrm{Ca}$ and soil $\mathrm{Mg}(r>$.78), whereas the second soil PC axis (hereafter $\mathrm{PC}_{\text {NUTRIENTS }}$ ) was positively correlated to soil $\mathrm{C}$, soil $\mathrm{N}$ and Olsen $\mathrm{P}$ concentration $(r>.66)$. All variables were scaled to unit variance prior to performing the PCA. The soil chemical composition variables ( $\mathrm{C}, \mathrm{N}$, Olsen $\mathrm{P}, \mathrm{Mg}, \mathrm{Ca}$ ) were log transformed to meet the assumptions for the PCA.

For all models presented here, continuous predictor variables, including the four new PC axes, were $z$-transformed to improve comparability among model parameters. In addition, for the sake of simplicity, no interactions among predictor variables were tested. Multicollinearity among predictor variables was assessed with the variance inflation factor (VIF) using the function vif from the $R$ package Car (Fox \& Weisberg, 2019).

A first set of models (design models) aimed to test the effects of the study design variables on PC1 $1_{\text {DEFENCE }}$ and PC2 $2_{\text {DEFENCE }}$, and on each of the nine plant traits in the four study species; that is, latitude, elevation, forest management type and distance to the forest edge were set as fixed effects in this group of models. Distance to the forest edge was log transformed (prior to the $z$-transformation) to meet model assumptions. Multicollinearity among predictor variables was weak in this model set (all VIF scores $<2.5$, Quinn \& Keough, 2002).

In a second set of models (environment models), the four study design variables were replaced by the environmental variables; that is, PC TEMPERATURE $_{\text {PRECIPITATION }}, \mathrm{PC}_{\mathrm{pH}}, \mathrm{PC}_{\text {NUTRIENTS }}$, PAI, $T_{\text {OFFSET }}$ MIN and $T_{\text {OFFSET }}$ MAX were set as fixed effects in this group of models. For the set of models with O. acetosella, PC PRECIPITATION $_{\text {was }}$ removed from all models due to multicollinearity with $\mathrm{PC}_{\text {TEMPERATURE }}$ (VIF » 10), for the set of models with M. effusum, PC PRECIPITATION $_{\text {and }}$ $T_{\text {OFFSET }}$ MAX was removed from all models due to multicollinearity

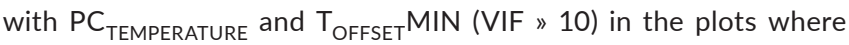
these species were sampled. After model adjustment, multicollinearity among predictor variables was weak (VIF $<10$ ), except for

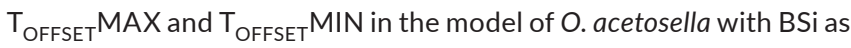
response variable (VIF < 12.5), which was tolerated.

In a final step, we performed variation partitioning analyses based on the environmental models (following Legendre \& Legendre, 2012) to assess the relative importance of macroclimate (PC TEMPERATURE, $_{\text {, }}$ $\mathrm{PC}_{\text {PRECIPITATION }}$ ), forest structure and microclimate (PAI, $\mathrm{T}_{\text {OFFSET }} \mathrm{MIN}$ and $\mathrm{T}_{\text {OFFSET }} \mathrm{MAX}$ ) and soil variables ( $\mathrm{PC}_{\mathrm{pH}}, \mathrm{PC}_{\text {NUTRIENTS }}$ ) on PC1 $1_{\text {DEFENCE }}$ and PC2 $2_{\text {DEFENCE }}$, and on each of the nine plant traits in the four study species. Prior to these analyses, PAI, T OFFSET MIN and T OFFSET $_{\text {MAX }}$ were summarized by the first two PCs resulting from a PCA (capturing $87 \%$ of the total variation) to obtain three balanced groups of each two predictor variables (i.e. macroclimate, microclimate and soil). We constructed LMMs containing each time one, two or three groups of predictor variables. Model fit was evaluated with the R package MuMln (Barton, 2017) by calculating the percentage of variation explained by the fixed effects $\left(R_{\mathrm{m}}^{2}\right)$ following Nakagawa and Schielzeth (2013). The 
amount of the variation explained by the unique and shared contribution of macroclimate, microclimate and soil variables was calculated as the proportion of explained variation relative to the $R_{m}^{2}$ of the global models (containing the three groups of predictor variables).

All analyses were performed in R (R Core Team, 2019).

\section{3 | RESULTS}

The nine traits that quantify plant resistance to herbivory were highly variable among the study species (Figure 2a, Supporting Information Table S3). Anemone nemorosa showed the highest trichome density, total phenolic concentration and $\mathrm{N}: \mathrm{P}$ ratio. Oxalis acetosella showed the highest SLA. The grasses ( $D$. cespitosa and M. effusum) had the highest concentration of $\mathrm{BSi}$, in contrast with the dicots (A. nemorosa and $\mathrm{O}$. acetosella), which showed the highest concentration of $\mathrm{Ca}$.

\subsection{Multivariate trends in physical and chemical plant traits}

The variation captured by the first two axes of the PCA, PC1 $1_{\text {DEFENCE }}$ and PC2 $2_{\text {DEFENCE}}$, ranged between $54 \%$ (A. nemorosa) and $70 \%$
(D. cespitosa) (Figure 3). For A. nemorosa, O. acetosella and M. effusum, we found that defence-related traits (trichome density, BSi, Ca, total phenolic concentration and $\mathrm{C}: \mathrm{N}$ ratio) were positively correlated to PC1 $1_{\text {DEFENCE }}$, and that traits associated with plant growth (SLA, N and P) were negatively correlated to PC1 $1_{\text {DEFENCE }}$. In contrast, for D. cespitosa we found that traits associated with plant growth (SLA, N and $\mathrm{P})$ and defence (total phenolic concentration, $\mathrm{Ca}$, and $\mathrm{BSi}$ ) were all positively correlated to $P C 1_{\text {DEFENCE }}$, while the plant $C: N$ ratio was negatively correlated with PC1 $1_{\text {DEFENCE }}$. The PC $2_{\text {DEFENCE }}$ axis did not show clear trends related to growth and defence traits.

\subsection{Effects of latitude, elevation, forest structure and distance to the forest edge}

Latitude had a positive effect on trichome density, $\mathrm{C}: \mathrm{N}$ ratio and $P C 1_{\text {DEFENCE }}$ in O. acetosella, and had a negative effect on the trichome density in $D$. cespitosa and on the $P$ concentration in $M$. effusum (Figure 2b). In contrast, elevation was a significant predictor for a greater range of traits, including PC $1_{\text {DEFENCE }}$ in $A$. nemorosa and $D$. cespitosa. In this set of species, elevation had a similar effect on several traits: the $C: N$ ratio increased, while the BSi and $\mathrm{N}$ concentration, $\mathrm{N}$ : $\mathrm{P}$ ratio and SLA decreased towards higher (a) Mean per species $\pm S D$

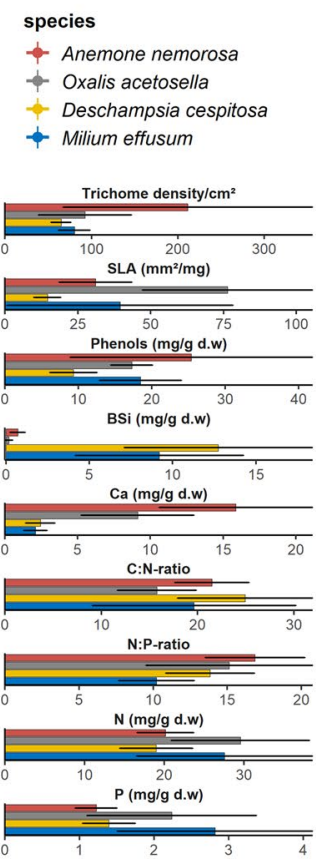

(b) Effects of design variables

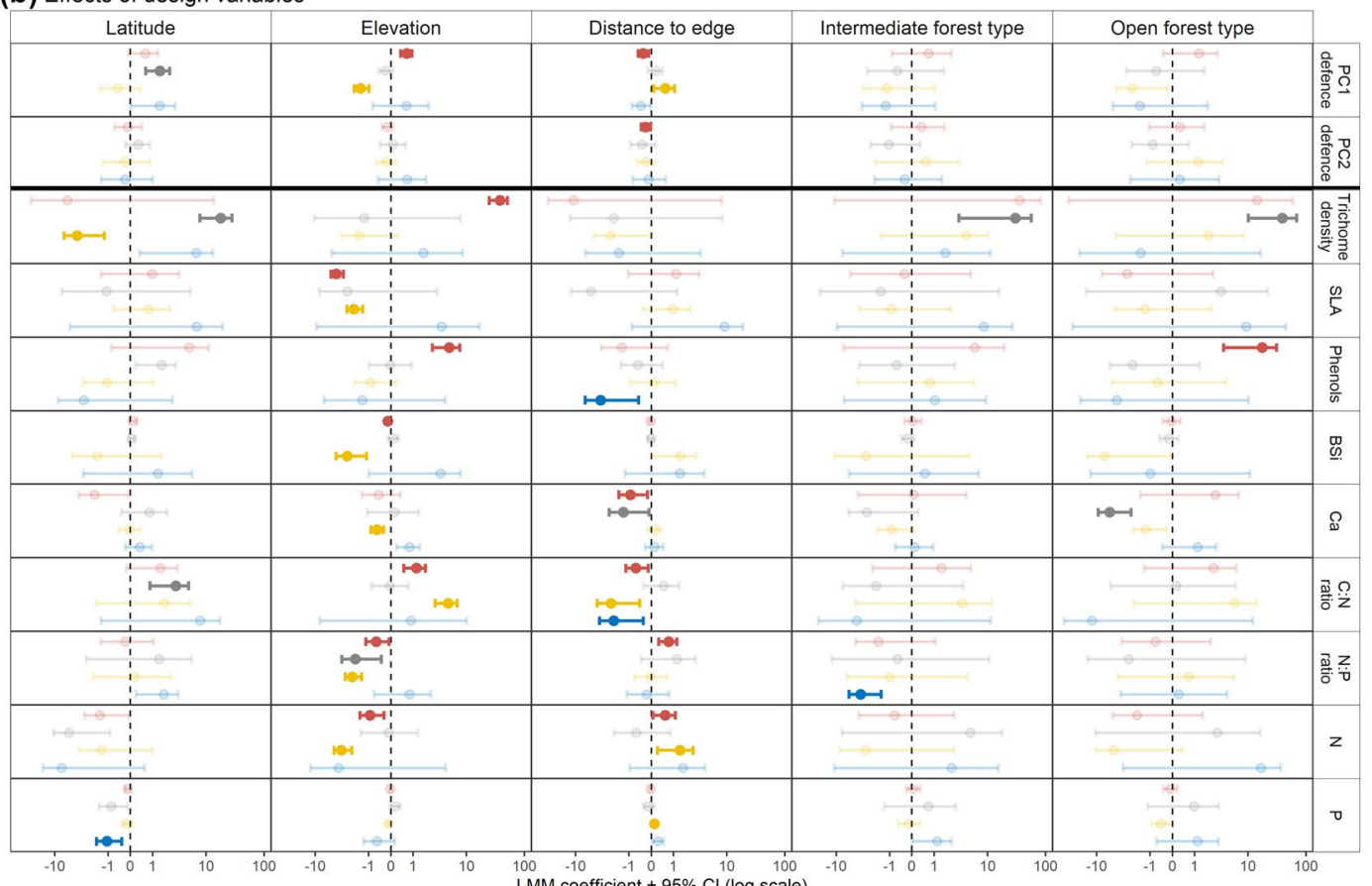

FIGURE 2 (a) Mean of plant trait values per species \pm standard deviation (SD) across 15 geographic sites in Europe. Chemical plant traits are expressed per mass dry weight (d.w.)(b) Log transformed linear mixed effect model (LMM) coefficient estimates [ $\pm 95 \%$ confidence intervals $(\mathrm{Cl})$ ] for latitude, elevation, distance to the forest edge and forest management type on two multivariate defence phenotypes [defence phenotype axis 1 (PC1 $1_{\text {DEFENCE }}$ ) and2(PC2 $\left.{ }_{\text {DEFENCE }}\right)$ ], and on trichome density, specific leaf area (SLA), biogenic silica concentration (BSi), total phenolic concentration (phenols), calcium concentration (Ca), carbon : nitrogen ( $\mathrm{C}: \mathrm{N}$ ratio), nitrogen : phosphorus ( $\mathrm{N}$ : $\mathrm{P}$ ratio), nitrogen concentration (N) and phosphorus concentration (P). The effects of 'Intermediate forest type' and 'Open forest type' are expressed relative to 'Dense forest type'. Significant effects $(p<.05)$ are plotted in bold. Non-significant effects $(p \geq .05)$ are faded 
(a)

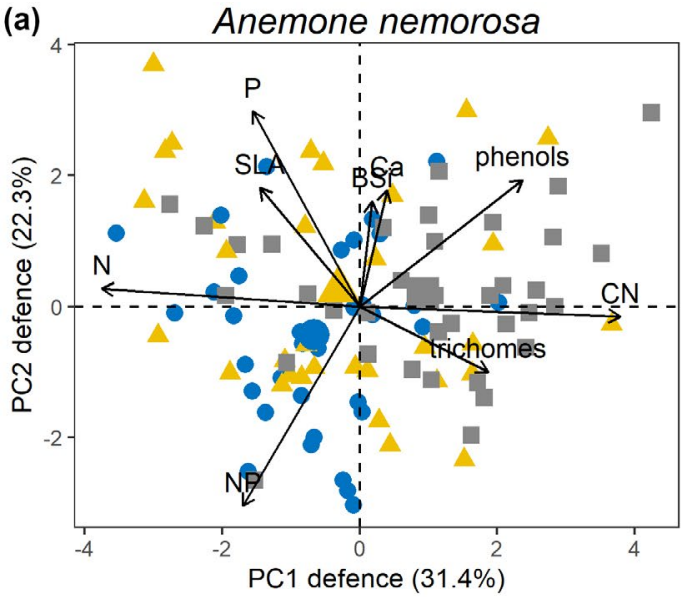

(c)

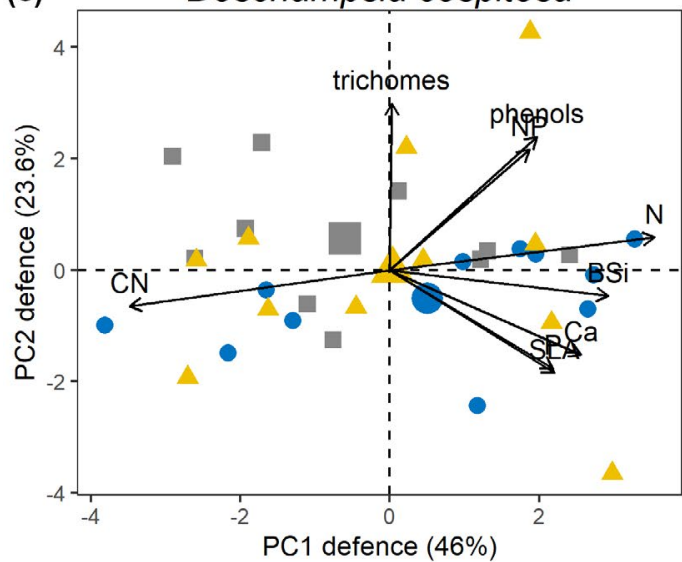

(b) Oxalis acetosella

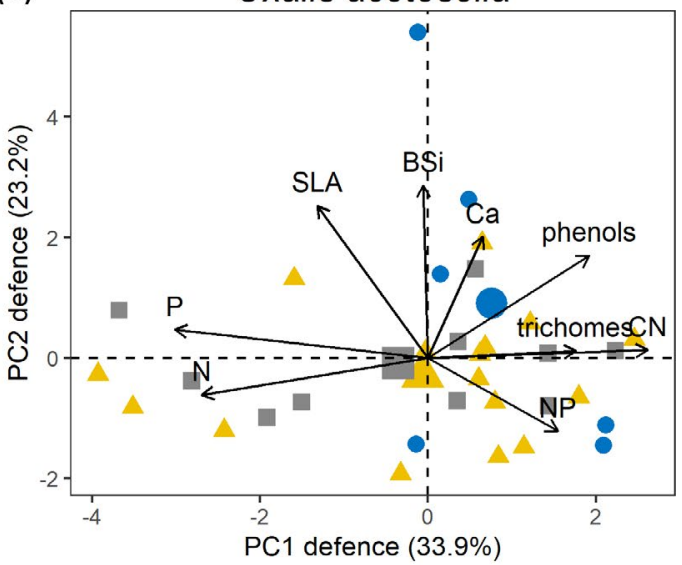

(d)

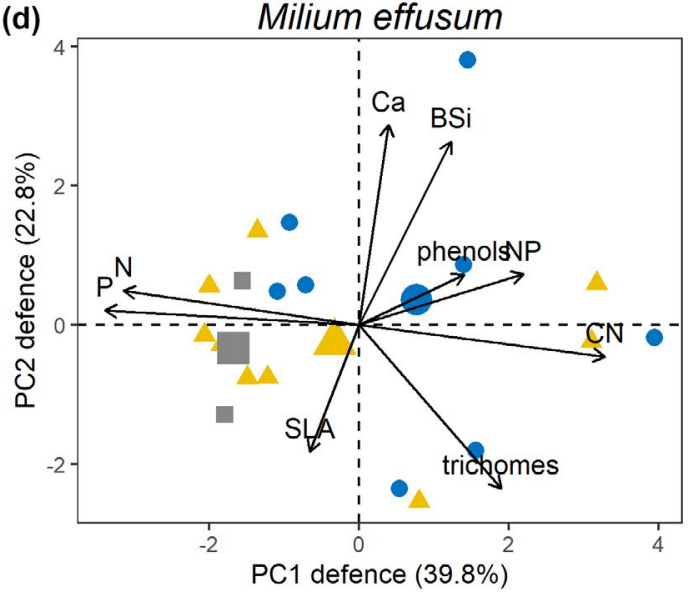

forest type Dense forest type Intermediate forest type $\square$ Open forest type

FIGURE 3 Biplots of sample coordinates and factor loading of trichome density (trichomes), specific leaf area (SLA), biogenic silica concentration (BSi), total phenolic concentration (phenols), calcium concentration ( $\mathrm{Ca}$ ), carbon : nitrogen (CN), nitrogen : phosphorus (NP), nitrogen concentration $(N)$, phosphorus concentration $(P)$ on the first two axes of the principal component analysis (PCA) for each individual per species. Colours and shapes refer to the type of management regime of the forest of the sample origins. The centroids of each group are represented by the larger symbols

elevations. Interestingly, we also observed significant trends in a great range of traits that could be attributed to local-scale factors: the effect of distance to the forest edge on PC1 $1_{\text {DEFENCE }}$ was negative for A. nemorosa, and positive for D. cespitosa. In addition, in this set of species, the $\mathrm{C}: \mathrm{N}$ ratio significantly decreased with distance to the edge as a consequence of increasing $\mathrm{N}$ concentrations. Forest management intensity had a positive effect on trichome density in A. nemorosa and $O$. acetosella and on the total phenolic concentration in A. nemorosa, and had a negative effect on the biogenic silica concentration in D. cespitosa and M. effusum.

\section{3 | Effects of environmental drivers}

The two macroclimate variables, $\mathrm{PC}_{\text {TEMPERATURE }}$ and PC PRECIPITATION, $_{\text {, }}$ were important predictors of several trait responses in the environmental models but we did not detect effects that were consistent over all species (Figure 4). In contrast, PC $_{\text {NUTRIENTS }}$ had a positive effect on the foliar $\mathrm{N}$ concentration in all species. Although not always significant, the $\mathrm{C}: \mathrm{N}$ ratio tended to decrease with increasing $\mathrm{PC}_{\text {NUTRIENTS }}$ in A. nemorosa and D. cespitosa. Importantly, PAI was a significant predictor for the greatest range of traits: PAI had a significant effect on PC1 $1_{\text {DEFENCE }}$ in all species. PAI had a positive effect on the foliar $\mathrm{N}$ concentration in all species, and, as a consequence, negatively affected the foliar $\mathrm{C}: \mathrm{N}$ ratio. We did not find consistent

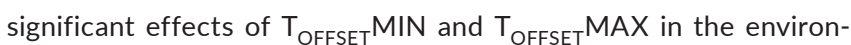
ment models.

When partitioning the proportion of the variation explained by the unique and shared contribution of macroclimate, forest microclimate and soil variables, we found that the unique effects of the microclimate variables and shared contribution of the macroand microclimate variables accounted for the largest proportion of explained variation of PC1 $1_{\text {DEFENCE }}$ in most species (Figure 5). In contrast, we found that the unique effects of the macroclimate 


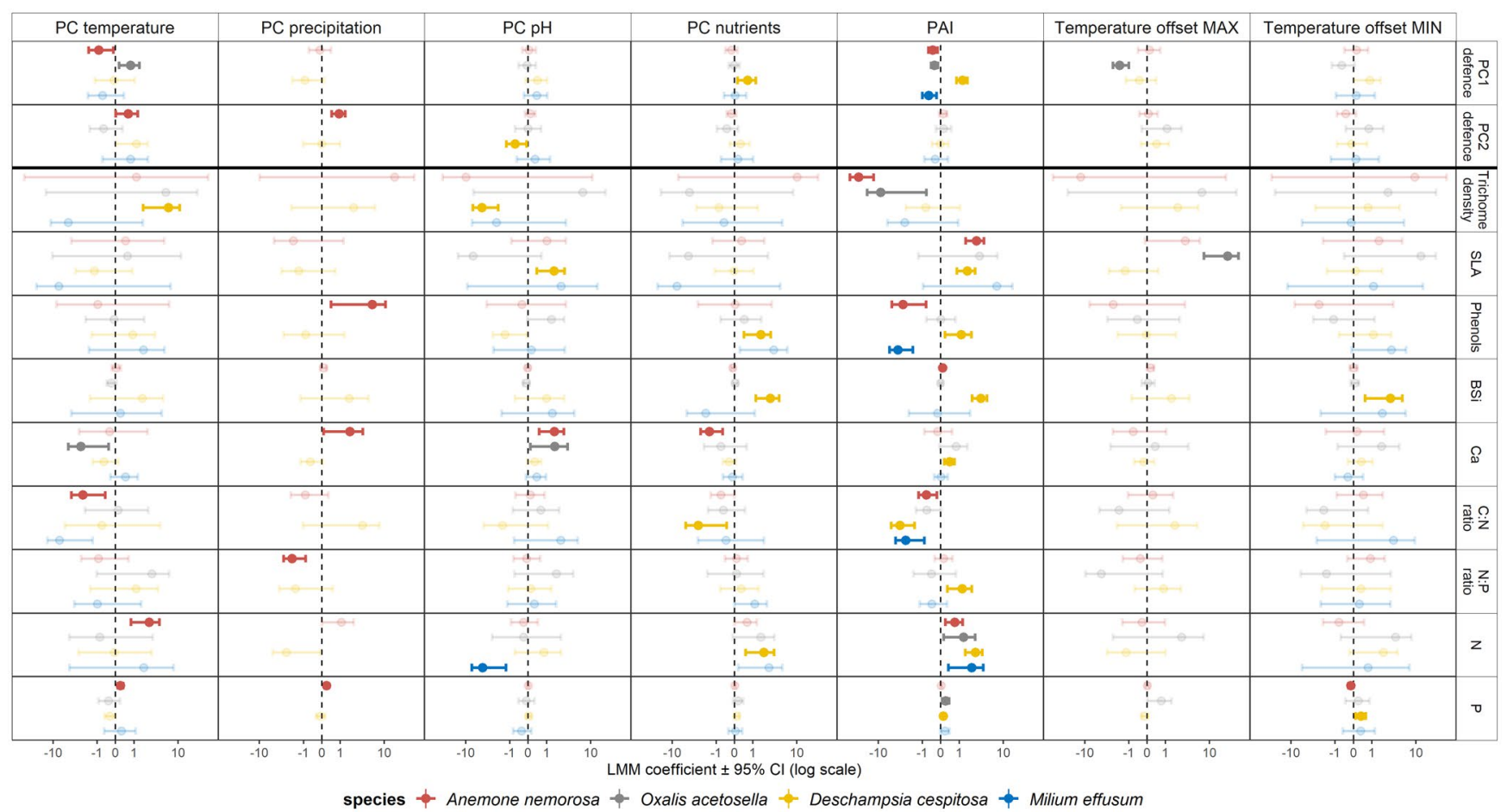

FIGURE 4 Log transformed linear mixed effect model (LMM) coefficient estimates [ \pm 95\% confidence intervals (CI)] for PC TEMPERATURE (multivariate macroclimate axis 1), $\mathrm{PC}_{\mathrm{PRECIPITATION}}$ (multivariate macroclimate axis 2), $\mathrm{PC}_{\mathrm{pH}}$ (multivariate soil axis 1), $\mathrm{PC}_{\mathrm{NUTRIENTS}}$ (multivariate soil axis 2), plant area index (PAI), mean daily maximum temperature offset value ( $\left.T_{\text {OFFSET }} M A X\right)$ and mean daily minimum temperature offset value ( $T_{\text {OFFSET }}$ MIN) on two multivariate defence phenotypes [defence phenotype axis 1 (PC1 $1_{D E F E N C E}$ ) and2 (PC2 $2_{\text {DEFENCE }}$ ), and on trichome density, specific leaf area (SLA), biogenic silica concentration (BSi), total phenolic concentration (phenols), calcium concentration (Ca), carbon : nitrogen ( $\mathrm{C}: \mathrm{N}$ ratio), nitrogen : phosphorus $(\mathrm{N}: \mathrm{P}$ ratio), nitrogen concentration $(\mathrm{N})$ and phosphorus concentration $(\mathrm{P})$. ForOxalis acetosella, PC PRECIPITATION $_{\text {was removed from all models due to multicollinearity with PC }}$ TEMPERATURE , for Milium effusum, PC PRECIPITATION $_{\text {and }}$ $T_{\text {OFFSET }}$ MAX were removed from all models due to multicollinearity with PC TEMPERATURE $_{\text {and T }}$ OFFSET MIN. Significant effects $(p<.05)$ are plotted in bold. Non-significant effects $(p \geq .05)$ are faded

variables accounted for the largest proportion of explained variation in PC2 ${ }_{\text {DEFENCE. }}$. The unique effects of the soil variables accounted for a large proportion of explained variation only for total phenolic concentration and $\mathrm{Ca}$ concentration in most species (Supporting Information Figure S7).

\section{4 | DISCUSSION}

This study integrates data from physical and chemical constitutively expressed plant traits related to defence and tolerance to herbivory in four common understorey plant species native to deciduous forests of Europe. We simultaneously studied the effects of the environment related to large-scale macroclimate gradients (i.e. latitude and elevation, PC TEMPERATURE and PC PRECIPITATION ) and to small-scale differences in forest microclimate (i.e. distance to the forest edge and forest management, PAI, T OFFSET $_{\text {MIN }}$ and $\left.T_{\text {OFFSET }} M A X\right)$ on a suite of nine traits associated with overall resistance to herbivory. Across all traits, we found no support for the hypothesis that plants are better adapted to cope with herbivory at lower latitudes. If anything, we found actually the opposite latitudinal pattern, with higher investment in defence traits at higher latitudes. Moreover, many of the other ecological drivers that were investigated explained more variation in defence traits than latitude. For example, distance to the forest edge was an important predictor of the overall plant defence phenotype (PC1 ${ }_{\text {DEFENCE }}$ ) in most species (Figure 2b). These clines in plants' investment in defence traits were attributed to environmental gradients related to forest microclimate. We found that variation in the traits was mainly driven by variation in topsoil nutrient concentration and, more importantly, forest structural complexity (Figure 4). As such, macroclimate gradients alone are insufficient to predict plant defence phenotypes (Figure 5 and Supporting Information Figure S7). These results highlight the importance of environmental changes at small spatial scales, relative to macroecological gradients, in driving patterns of plant defence investment.

\section{1 | Multiple plant traits contribute to the overall defence phenotype}

Plants do not rely on a single trait to cope with herbivores (Agrawal, 2007; Duffey \& Stout, 1996; Loranger et al., 2012; Moles et al., 2013). Rather, an arsenal of functional traits contribute to the overall plant defence phenotype. Most research initiatives to date, however, have focused on one or a few defence-related traits that 
(a) Marginal $R^{2}$ global model

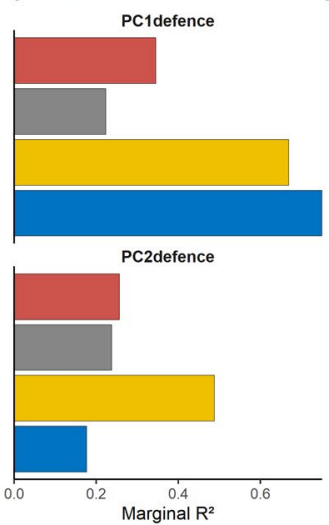

(b) Variation partitioning across three groups of environmental variables

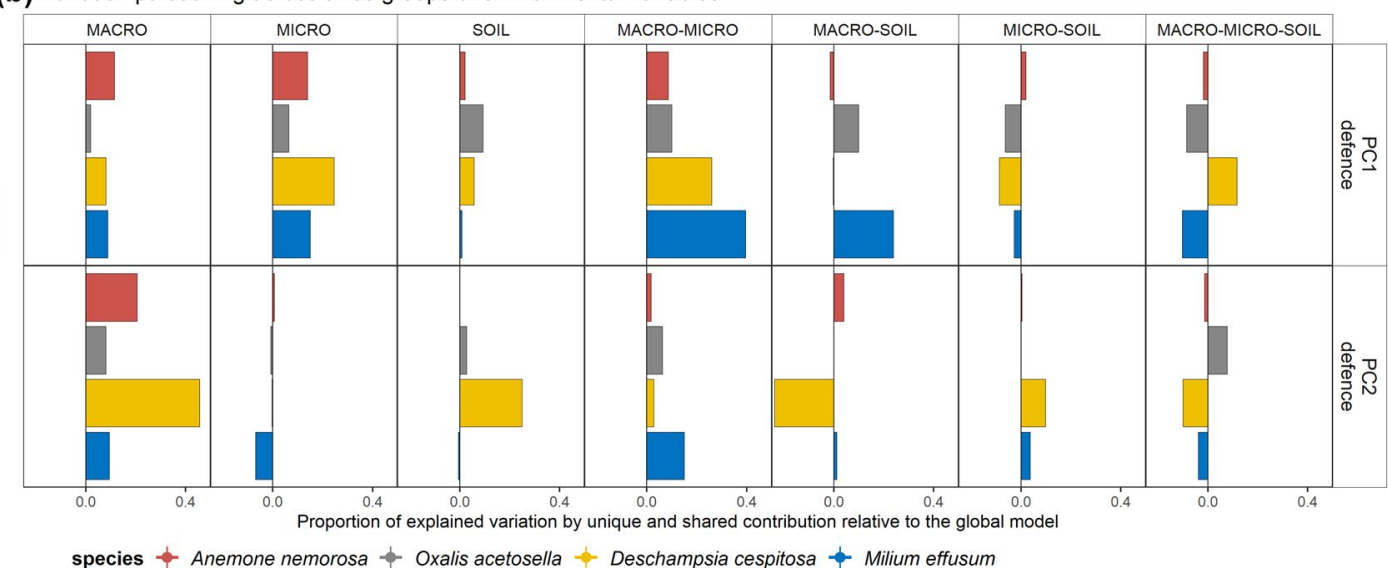

FIGURE 5 (a) Proportion of the variation explained by the fixed effects (marginal $R^{2}, R_{\mathrm{m}}^{2}$ ) in the global linear mixed effect models (those that include all the predictor variables) with the response variables defence phenotype axis 1 (PC1 $1_{\text {DEFENCE }}$ and2 (PC2 $2_{\text {DEFENCE }}$. (b) Results of the variation partitioning across three group of environmental predictor variables: MACRO (including the macroclimate variables

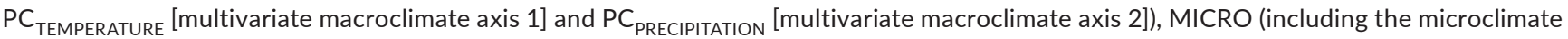
variables $\mathrm{PC}_{\mathrm{PAI}}$ [multivariate microclimate axis 1] and $\mathrm{PC}_{\mathrm{T}_{\text {_OFFSET_MIN }}}$ [multivariate microclimate axis 2]) and SOIL (including the soil variables $\mathrm{PC}_{\mathrm{pH}}$ [multivariate soil axis 1] and $\mathrm{PC}_{\text {NUTRIENTS }}$ [multivariate soil axis 2]). The amount of the variation explained by the unique and shared contribution of macroclimate, microclimate and soil variables was calculated as the proportion of explained variation relative to the $R^{2}$ of the global models (containing the three groups of predictor variables)

are treated independently, even though appropriate multivariate applications (e.g. PCA) are available and frequently proposed as the way forward to analyse complex phenotypes (Defossez et al., 2018; Loranger et al., 2012; Moreira, Petry, et al., 2018). Here, we simultaneously analysed a suite of nine physical and chemical plant traits that contribute to herbivory resistance. For most species (i.e. A. nemorosa, O. acetosella and M. effusum), we found a trade-off between the group of traits associated with plant defence and the group of traits associated with plant growth (Figure 3 ). These results are in line with the predictions posed by the optimal defence theory (McKey, 1974). This ecological theory predicts an adaptive value of resource allocation to defence only when the associated benefits outweighs the costs of losing plant tissue. In other words, if the metabolic cost of investment in defence traits is lower than the cost of losing leaf tissue, then plants primarily invest in expensive defence traits (i.e. conservative strategy), otherwise, plants invest more in cheap and fast-growing tissue (i.e. acquisitive strategy). In this view, a species' realized niche is thus not only a product of the abiotic context of the environment (e.g. soil nutrient levels, light availability), but likely also modulated by a complex interplay among biotic (e.g. herbivores) and abiotic factors inherent to its niche.

Unexpectedly, we did not find such a trade-off for D. cespitosa. This species showed a positive correlation among traits associated with plant growth and total phenolic concentration, foliar BSi and $\mathrm{Ca}$ concentration when all the variation was summarized by PC $1_{\text {DEFENCE }}$ (Figure 3). This group of traits correlated oppositely to the $\mathrm{C}: \mathrm{N}$ ratio. Trichome density was relatively unrelated to these two groups of traits. Deschampsia cespitosa is a species known for its extremely high levels of BSi, stored in spiny trichomes and phytoliths, which efficiently reduce herbivore damage (Davy, 1980). Due to its intrinsic slow growth rate caused by considerable self-shading and compact growth form, this species has a poor competitive ability in forests, but is tolerant to harsh abiotic conditions (Davy, 1980). Although D. cespitosa tolerates a wide range of soil humidity (Davy, 1980), in natural communities, this species is completely excluded from welldrained and nutrient rich soils (Rahman \& Rutter, 1980), conditions that are typically dominated by species with strongly developed acquisitive strategies. As such, we postulate that D. cespitosa has an intrinsic conservative growing strategy leading the ecological cost of allocating resources to defence traits to be not the major constraint for plant growth (Endara \& Coley, 2011).

In summary, we conclude that the multivariate defence phenotype of plants, as defined by PC $1_{\text {DEFENCE }}$, can help to understand how clines in the environment simultaneously shape multiple plant traits associated with overall resistance to herbivory. Nevertheless, individual trait responses to environmental gradients are also important to consider to identify multiple trait functions that are potentially under selection of conflicting gradients relative to herbivory (e.g. leaf trichomes).

\subsection{Variation in plant defence and tolerance traits is associated with environmental clines at small spatial scales}

Our results do not support the long-standing hypothesis that plants invest more in defence traits at lower latitudes to cope with a stronger herbivore pressure (Figure 2b). Although the latitudinal sample distribution covered $34 \%$ (M. effusum, $11^{\circ} \Delta$ latitude) to $88 \%$ (A. nemorosa, $20^{\circ} \Delta$ latitude) of the species' latitudinal ranges, these gradients are restricted 
to the boreal-temperate-Mediterranean biome. Therefore, conclusions may not hold for other ecosystems such as the tropics. Nevertheless, our sampled gradient covered more than $10^{\circ} \mathrm{C}$ in mean annual temperature and more than a threefold change in annual precipitation regimes. Surprisingly these factors alone played a minor role in shaping plant defence phenotypes (Figure 5 and Supporting Information Figure S7), and significant trait responses to these large-scale macroclimate gradients were often species dependent (Figure 4). Interestingly, species showed more similar trait responses to local-scale environmental gradients. Indeed, we could attribute trait variability to variation in topsoil nutrient concentration (i.e. PC $_{\text {NUTRIENTS }}$ ) and, more importantly, forest structural complexity (i.e. PAI). As such, not only macroclimatic conditions, but also subtle differences in forest microclimate and soil characteristics played a major role in modulating plant defence phenotypes.

Soil nutrient concentration was positively related to the foliar $\mathrm{N}$ concentration and negatively related to the $\mathrm{C}: \mathrm{N}$ ratio. This pattern was previously described for forest understorey species growing in optimal light conditions (Elemans, 2004) and follows predictions posed by the resource availability hypothesis (Coley et al., 1985). This hypothesis states that plants living in resource-poor environments have inherently slow growth rates but highly defended tissue as the cost of replacing tissues consumed by herbivores is higher. In contrast, plants growing in resource-rich environments tend to produce cheap and fast growing tissues (Endara \& Coley, 2011).

Besides soil nutrients, light is considered as the main limiting resource for understorey species in temperate forests (Landuyt et al., 2019), and directly modulates important plant functional traits such as foliar N and SLA (Blondeel et al., 2019). In our models, light availability was included as a function of forest structural complexity denoted by PAI. The amount of light that reaches the forest floor is expected to decrease with increasing PAI. We found significant positive effects of PAI on the foliar $\mathrm{N}$ concentration in all species. Such a modulating role of light on foliar $\mathrm{N}$ concentrations was previously reported for understorey species (Blondeel et al., 2019; Elemans, 2004) and could indicate a compensatory mechanism where plants allocate more $\mathrm{N}$ to photosynthetic tissue that is used in compounds responsible for light harvesting (Niinemets, 1997). Alternatively, foliar $\mathrm{N}$ concentrations can also decrease in response to increasing light availability due to an indirect effect of plant tissue nutrient dilution (Sardans et al., 2017), caused by enhanced leaf carbon uptake under elevated light conditions while nutrient uptake remains nearly constant (e.g. Blondeel et al., 2019). Indeed, we found that the $C: N$ ratio tended to decrease with increasing PAI.

Finally, we found that PAI was an important predictor of PC1 $1_{\text {DEFENCE }}$ in all species. In line with de Vries et al. (2019), we conclude that the ecological costs for understorey plants to allocate resources to growth versus defence traits are predominantly determined by light availability. These results underpin the building blocks of the resource availability hypothesis (Coley et al., 1985), given that light is the main limiting resource for understorey plants (Landuyt et al., 2019).
It is important to note that our study design did not allow us to explicitly differentiate between constitutive and induced levels of trait expression as we did not quantify variation in herbivore pressure. Nevertheless, all traits are constitutively expressed and several address tolerance traits that reflect the nutritional quality of the plant. As such, biotic and abiotic factors form the entire growing season have contributed to the observed levels of these traits. Our results, therefore, apply to the overall (constitutive) plant defence and tolerance as determined by long-term patterns of herbivore pressure. Future research addressing the inducibility of both defence and tolerance traits in response to herbivore feeding will contribute to a better understanding of the importance of induced trait responses in shaping patterns along environmental gradients. Forest edge-to-core transects can in this context act as an extremely useful study system as they are characterized by strong biotic and abiotic clines over a small spatial scale (De Frenne et al., 2019; De Smedt et al., 2019; Govaert et al., 2020; Lantman et al., 2019; Meeussen et al., 2020; Murcia, 1995; Remy et al., 2016).

In conclusion, our results show clear evidence that variation in the plant defence phenotype is strongly coupled to environmental clines at small spatial scales. As such, macroclimate gradients alone are insufficient to predict plant defence phenotypes. These findings highlight the importance of the local habitat structure and environmental conditions in modulating plant resistance to herbivory, but also raise the question to what extent an individual trait response is a product of local adaptation versus phenotypic plasticity. In our study, it is likely that trait plasticity played a more important role than genetic adaptation given the short spatial scale of the forest transects (i.e. $100 \mathrm{~m}$ ). Future research that investigates latitudinal or elevation patterns in plant defence traits should aim to quantify to what degree trait variation is linked to environmental variation at small spatial scales, and ultimately needs to include a suite of plant traits associated with overall resistance to herbivory. Such an integrated framework will contribute to our understanding of the patterns in plant defence traits along environmental gradients related to small and large spatial scales.

\section{ACKNOWLEDGMENTS}

We thank Luc Willems, Greet De bruyn, Beatriz Lago, Mario Vande Velde, Frederic Dumoulin and Christ'I Detavernier for performing the chemical analyses. We thank Evy Ampoorter, Haben Blondeel, Filip Ceunen, Kris Ceunen, Robbe De Beelde, Emiel De Lombaerde, Lionel Hertzog, Dries Landuyt, Pierre Lhoir, Audrey Peiffer, Michael Perring, Sanne Van Den Berge, Lotte Van Nevel, Mia Vedel-Sørensen and Matteo Tolosano for their assistance during the fieldwork campaign. We thank Helena Tavernier, Geydis Reinoso, Sandra De Gendt and Karel Vercruysse for the SLA measurements.

\section{AUTHOR CONTRIBUTIONS}

PDF, SG, PVG, CM, KV and PS designed the research. All authors collected data. PS performed the data analyses. PS wrote the manuscript, with contributions from PDF and PVG. All authors contributed substantially to revisions. 


\section{DATA AVAILABILITY STATEMENT}

Raw data related to this manuscript are available on Figshare: https:// doi.org/10.6084/m9.figshare.12999101.v1

\section{ORCID}

Pieter Sanczuk (ID) https://orcid.org/0000-0003-1107-4905

Sanne Govaert (iD https://orcid.org/0000-0002-8939-1305

Camille Meeussen (iD https://orcid.org/0000-0002-5869-4936

Karen De Pauw iD https://orcid.org/0000-0001-8369-2679

Thomas Vanneste (iD https://orcid.org/0000-0001-5296-917X

Leen Depauw (ID https://orcid.org/0000-0001-5703-6811 Jonas Schoelynck iD https://orcid.org/0000-0003-0166-280X Marthe De Boevre iD https://orcid.org/0000-0002-6151-5126 Sarah De Saeger iD https://orcid.org/0000-0002-2160-7253 Kurt Bollmann (iD https://orcid.org/0000-0002-4690-7121 Jörg Brunet iD https://orcid.org/0000-0003-2667-4575 Sara A. O. Cousins iD https://orcid.org/0000-0003-2656-2645 Jan Plue iD https://orcid.org/0000-0002-6999-669X Martin Diekmann (iD https://orcid.org/0000-0001-8482-0679 Bente J. Graae (iD https://orcid.org/0000-0002-5568-4759 Per-Ola Hedwall iD https://orcid.org/0000-0002-0120-7420 Giovanni lacopetti iD https://orcid.org/0000-0002-1472-4435 Jonathan Lenoir (iD https://orcid.org/0000-0003-0638-9582 Anna Orczewska iD https://orcid.org/0000-0002-7924-9794 Quentin Ponette iD https://orcid.org/0000-0002-2726-7392 Federico Selvi iD https://orcid.org/0000-0002-3820-125X Fabien Spicher (ID) https://orcid.org/0000-0002-9999-955X Kim Calders (iD https://orcid.org/0000-0002-4562-2538 Hans Verbeeck (ID) https://orcid.org/0000-0003-1490-0168 Kris Verheyen (iD https://orcid.org/0000-0002-2067-9108 Pieter Vangansbeke iD https://orcid.org/0000-0002-6356-2858 Pieter De Frenne iD https://orcid.org/0000-0002-8613-0943

\section{REFERENCES}

Abdala-Roberts, L., Moreira, X., Rasmann, S., Parra-Tabla, V., \& Mooney, K. A. (2016). Test of biotic and abiotic correlates of latitudinal variation in defences in the perennial herb Ruellia nudiflora. Journal of Ecology, 104(2), 580-590. https://doi.org/10.1111/1365-2745.12512

Abdala-Roberts, L., Rasmann, S., Berny-Mier y Terán, J. C., Covelo, F., Glauser, G., \& Moreira, X. (2016). Biotic and abiotic factors associated with altitudinal variation in plant traits and herbivory in a dominant oak species. American Journal of Botany, 103(12), 2070-2078. https://doi.org/10.3732/ajb.1600310

Agrawal, A. A. (2007). Macroevolution of plant defense strategies. Trends in Ecology and Evolution, 22(2), 103-109. https://doi.org/10.1016/j. tree.2006.10.012

Agrawal, A. A. (2019). A scale-dependent framework for trade-offs, syndromes, and specialization in organismal biology. Ecology, 101(2), 1-24. https://doi.org/10.1002/ecy.2924

Agrawal, A. A., \& Fishbein, M. (2006). Plant defense syndromes. Ecology, 87(Suppl. 7), 132-149. 10.1890/0012-9658(2006)87[132:pds]2.0.co;2

Agrawal, A. A., \& Weber, M. G. (2015). On the study of plant defence and herbivory using comparative approaches: How important are secondary plant compounds. Ecology Letters, 18(10), 985-991. https:// doi.org/10.1111/ele.12482

Barton, K. (2017). MuMIn: Multi-model inference. R package version 1.4.3.6. https://CRAN.R-project.org/package $=$ MuMIn
Blondeel, H., Remy, E., Perring, M. P., Landuyt, D., Bodé, S., De Frenne, P., Boeckx, P., \& Verheyen, K. (2019). Larger direct than indirect effects of multiple environmental changes on leaf nitrogen of forest herbs. Plant and Soil, 445, 199-216. https://doi.org/10.1007/s1110 4-019-04298-1

Buckley, J., Widmer, A., Mescher, M. C., \& De Moraes, C. M. (2019). Variation in growth and defence traits among plant populations at different elevations: Implications for adaptation to climate change. Journal of Ecology, 107(5), 2478-2492. https://doi. org/10.1111/1365-2745.13171

Calders, K., Origo, N., Disney, M., Nightingale, J., Woodgate, W., Armston, J., \& Lewis, P. (2018). Variability and bias in active and passive ground-based measurements of effective plant, wood and leaf area index. Agricultural and Forest Meteorology, 252, 231-240. https://doi.org/10.1016/j.agrformet.2018.01.029

Carmona, D., Lajeunesse, M. J., \& Johnson, M. T. J. (2011). Plant traits that predict resistance to herbivores. Functional Ecology, 25(2), 358367. https://doi.org/10.1111/j.1365-2435.2010.01794

Coley, P. D., \& Barone, J. A. (1996). Herbivory and plant defenses in tropical forests. Annual Review of Ecology and Systematics, 27, 305-335. https://doi.org/10.1146/annurev.ecolsys.27.1.305

Coley, P. D., Bryant, J. P., \& Chapin, F. S. (1985). Resource availability and plant antiherbivore defense. Science, 230(4728), 895-899. https:// doi.org/10.1126/science.230.4728.895

Davy, A. J. (1980). Biological flora of the British Isles. Journal of Ecology, 38(1), 107-138.

De Frenne, P., Brunet, J., Cougnon, M., Decocq, G., Graae, B.J., Hagenblad, J., Hermy, M., Kolb, A., Lemke, I. H., Ma, S., \& Orczewska, A. (2017). Biological flora of the British Isles: Milium effusum. Journal of Ecology, 105(3), 839-858. https://doi.org/10.1111/1365-2745.12744

De Frenne, P., Graae, B. J., Rodríguez-Sánchez, F., Kolb, A., Chabrerie, O., Decocq, G., Kort, H., Schrijver, A. N., Diekmann, M., Eriksson, O., Gruwez, R., Hermy, M., Lenoir, J., Plue, J., Coomes, D. A., \& Verheyen, K. (2013). Latitudinal gradients as natural laboratories to infer species' responses to temperature. Journal of Ecology, 101(3), 784-795. https://doi.org/10.1111/1365-2745.12074

De Frenne, P., Kolb, A., Graae, B. J., Decocq, G., Baltora, S., De Schrijver, A., Brunet, J., Chabrerie, O., Cousins, S. A. O., Dhondt, R., Diekmann, M., Gruwez, R., Heinken, T., Hermy, M., Liira, J., Saguez, R., Shevtsova, A., Baskin, C. C., \& Verheyen, K. (2011). A latitudinal gradient in seed nutrients of the forest herb Anemone nemorosa. Plant Biology, 13(3), 493-501. https://doi.org/10.1111/j.1438-8677.2010.00404.x

De Frenne, P., Zellweger, F., Rodríguez-Sánchez, F., Scheffers, B. R., Hylander, K., Luoto, M., Vellend, M., Verheyen, K., \& Lenoir, J. (2019). Global buffering of temperatures under forest canopies. Nature Ecology \& Evolution, 3, 744-749. https://doi.org/10.1038/s4155 9-019-0842-1

De Smedt, P., Baeten, L., Gallet-Moron, E., Brunet, J., Cousins, S. A. O., Decocq, G., Deconchat, M., Diekman, M., Giffard, B., Kalda, O., Liira, J., Paal, T., Wulf, M., Hermy, M., \& Verheyen, K. (2019). Forest edges reduce slug (but not snail) activity-density across Western Europe. Pedobiologia-Journal of Soil Ecology, 75, 34-37. https://doi. org/10.1016/j.pedobi.2019.05.004

de Vries, J., Evers, J. B., Dicke, M., \& Poelman, E. H. (2019). Ecological interactions shape the adaptive value of plant defence: Herbivore attack versus competition for light. Functional Ecology, 33(1), 129-138. https://doi.org/10.1111/1365-2435.13234

Defossez, E., Pellissier, L., \& Rasmann, S. (2018). The unfolding of plant growth form-defence syndromes along elevation gradients. Ecology Letters, 21(5), 609-618. https://doi.org/10.1111/ele.12926

Demaster, D. J. (1981). The supply and accumulation of silica in the marine environment. Geochimica et Cosmochimica Acta, 45(10), 17151732. https://doi.org/10.1016/0016-7037(81)90006-5

Descombes, P., Kergunteuil, A., Glauser, G., Rasmann, S., \& Pellissier, L. (2019). Plant physical and chemical traits associated with herbivory 
in situ and under a warming treatment. Journal of Ecology, 108(2), 1-17. https://doi.org/10.1111/1365-2745.13286

Dobzhansky, T. (1950). Evolution in the tropics. American Scientist, 38 , 209-221.

Duffey, S. S., \& Stout, M. J. (1996). Antinutritive and toxic components of plant defense against insects. Archives of Insect Biochemistry and Physiology, 32(1), 3-37. 10.1002/(SICI)1520-6327(1996) 32:1<3:AID-ARCH2>3.0.CO;2-1

Elemans, M. (2004). Light, nutrients and the growth of herbaceous forest species. International Journal of Ecology, 26, 197-202. https://doi. org/10.1016/j.actao.2004.05.003

Endara, M.-J., \& Coley, P. D. (2011). The resource availability hypothesis revisited: A meta-analysis. Functional Ecology, 25, 389-398. https:// doi.org/10.1111/j.1365-2435.2010.01803.x

Fox, J., \& Weisberg, S. (2019). An R companion to applied regression (3rd ed.). Sage.

Galmán, A., Abdala-Roberts, L., Zhang, S., Berny-Mier y Teran, J. C., Rasmann, S., \& Moreira, X. (2018). A global analysis of elevational gradients in leaf herbivory and its underlying drivers: Effects of plant growth form, leaf habit and climatic correlates. Journal of Ecology, 106(1), 413-421. https://doi.org/10.1111/1365-2745.12866

Gaston, K. J. (2000). Global patterns in biodiversity. Nature, 405(6783), 220-227. https://doi.org/10.1038/35012228

Gilbert, J., Gowing, D., \& Wallace, H. (2009). Available soil phosphorus in semi-natural grasslands: Assessment methods and community tolerances. Biological Conservation, 142(5), 1074-1083. https://doi. org/10.1016/j.biocon.2009.01.018

Gonzáles, W. L., Negritto, M. A., Suárez, L. H., \& Gianoli, E. (2008). Induction of glandular and non-glandular trichomes by damage in leaves of Madia sativa under contrasting water regimes. Acta Oecologica, 33, 128-132. https://doi.org/10.1016/j. actao.2007.10.004

Govaert, S., Meeussen, C., Vanneste, T., Bollmann, K., Brunet, J., Cousins, S. A. O., Diekmann, M., Graae, B. J., Hedwall, P.-O., Heinken, T., lacopetti, G., Lenoir, J., Lindmo, S., Orczewska, A., Perring, M. P., Ponette, Q., Plue, J., Selvi, F., Spicher, F., ... De Frenne, P. (2020). Edge influence on understorey plant communities depends on forest management. Journal of Vegetation Science, 31(2), 281-292. https://doi. org/10.1111/jvs.12844

Haddad, N. M., \& Hicks, W. M. (2000). Host pubescence and the behavior and performance of the butterfly Papilio Troilus (Lepidoptera: Papilionidae). Environmental Entomology, 29(2), 299-303.

Hultén, E., \& Fries, M. (1986). Atlas of North European Vascular plants: North of the tropic of cancer I-III. Königstein, Germany: Koeltz Scientific Books. https://doi.org/10.1111/j.1756-1051.1988.tb017 02.x

Iddles, T. L., Read, J., \& Sanson, G. D. (2003). The potential contribution of biomechanical properties to anti-herbivore defence in seedlings of six Australian rainforest trees. Australian Journal of Botany, 51(1), 119-128. https://doi.org/10.1071/BT02060

ISO 11277. (2009). Soil quality - Determination of particle size distribution in mineral soil material - Method by sieving and sedimentation. Geneva: ISO.

Janzen, D. H. (1970). Herbivores and the number of tree species in tropical forests. The American Naturalist, 104(940), 501-528. https://doi. org/10.1086/282687

Josse, J., \& Husson, F. (2016). missMDA: A package for handling missing values in multivariate data analysis. Journal of Statistical Software, 70(1), 1-12. https://doi.org/10.18637/jss.v070.i01

Karger, D. N., Conrad, O., Böhner, J., Kawohl, T., Kreft, H., Soria-Auza, R. W., Zimmermann, N. E., Linder, H. P., \& Kessler, M. (2017). Climatologies at high resolution for the earth's land surface areas. Scientific Data, 4, 1-20. https://doi.org/10.1038/sdata.2017.122

Kooyers, N. J., Blackman, B. K., \& Holeski, L. M. (2017). Optimal defense theory explains deviations from latitudinal herbivory defense hypothesis. Ecology, 98(4), 1036-1048. https://doi.org/10.1002/ ecy.1731

Kurokawa, H., Peltzer, D. A., \& Wardle, D. A. (2010). Plant traits, leaf palatability and litter decomposability for co-occurring woody species differing in invasion status and nitrogen fixation ability. Functional Ecology, 24(3), 513-523. https://doi. org/10.1111/j.1365-2435.2009.01676.x

Labandeira, C. C. (1998). Early history of arthropod and vascular plant associations. Annual Review of Earth and Planetary Sciences, 26(1), 329-377. https://doi.org/10.1146/annurev.earth.26.1.329

Lajtha, K., Driscoll, C., Jarrell, W., \& Elliott, E. (1999). Soil phosphorus: Characterization and total element analysis. In G. P. Robertson, D. C. Coleman, C. S. Bledsoe, \& P. Sollins (Eds.), Standard soil methods for long-term ecological research (pp. 115-142). Oxford University Press.

Landuyt, D., De Lombaerde, E., Perring, M. P., Hertzog, L. R., Ampoorter, E., Maes, S. L., De Frenne, P., Ma, S., Proesmans, W., Blondeel, H., Sercu, B. K., Wang, B., Wasof, S., \& Verheyen, K. (2019). The functional role of temperate forest understorey vegetation in a changing world. Global Change Biology, 25(11), 3625-3641. https://doi. org/10.1111/gcb.14756

Lantman, I. M. V. S., Hertzog, L. R., Vandegehuchte, M. L., Martel, A. N., Verheyen, K., Lens, L., \& Bonte, D. (2019). Forest edges, tree diversity and tree identity change leaf miner diversity in a temperate forest. Insect Conservation and Diversity, 13(1), 10-22. https://doi. org/10.1111/icad.12358

Lê, S., Josse, J., \& Husson, F. (2008). FactoMineR: An R package for multivariate analysis. Journal of Statistical Software, 25(1), 1-18.

Legendre, P., \& Legendre, L. (2012). Numerical ecology. Elsevier.

Loranger, J., Meyer, S. T., Shipley, B., Kattge, J., Loranger, H., Roscher, C., \& Weisser, W. W. (2012). Predicting invertebrate herbivory from plant traits: Evidence from 51 grassland species in experimental monocultures. Ecology, 93(12), 2674-2682. https://doi. org/10.1890/12-0328.1

Loughnan, D., \& Williams, J. L. (2019). Climate and leaf traits, not latitude, explain variation in plant-herbivore interactions across a species' range. Journal of Ecology, 107(2), 913-922. https://doi. org/10.1111/1365-2745.13065

Lynn, J. S., \& Fridley, J. D. (2019). Geographic patterns of plant-herbivore interactions are driven by soil fertility. Journal of Plant Ecology, 12(4), 653-661. https://doi.org/10.1093/jpe/rtz002

Massey, F. P., Ennos, A. R., \& Hartley, S. (2007). Grasses and the resource availability hypothesis: The importance of silica-based defences. Journal of Ecology, 95, 414-424. https://doi. org/10.1111/j.1365-2745.2007.01223.x

McKey, D. (1974). Adaptive patterns in alkaloid physiology. The American Naturalist, 108(961), 305-320. https://doi.org/10.1086/282909

Meeussen, C., Govaert, S., Vanneste, T., Calders, K., Bollmann, K., Brunet, J., Cousins, S. A. O., Diekmann, M., Graae, B. J., Hedwall, P.-O., Krishna Moorthy, S. M., lacopetti, G., Lenoir, J., Lindmo, S., Orczewska, A., Ponette, Q., Plue, J., Selvi, F., Spicher, F., ... De Frenne, P. (2020). Structural variation of forest edges across Europe. Forest Ecology and Management, 462, 117-929. https://doi.org/10.1016/J. FORECO.2020.117929

Moles, A. T., Bonser, S. P., Poore, A. G. B., Wallis, I. R., \& Foley, W. J. (2011). Assessing the evidence for latitudinal gradients in plant defence and herbivory. Functional Ecology, 25(2), 380-388. https://doi. org/10.1111/j.1365-2435.2010.01814.x

Moles, A. T., Peco, B., Wallis, I. R., Foley, W. J., Poore, A. G. B., Seabloom, E. W., Vesk, P. A., Bisigato, A. J., Cella-Pizarro, L., Clark, C. J., Cohen, P. S., Cornwell, W. K., Edwards, W., Ejrnaes, R., Gonzales-Ojeda, T., Graae, B. J., Hay, G., Lumbwe, F. C., Magaña-Rodríguez, B., ... Hui, F. K. C. (2013). Correlations between physical and chemical defences in plants: Tradeoffs, syndromes, or just many different ways to skin a herbivorous cat? New Phytologist, 198(1), 252-263. https://doi. org/10.1111/nph.12116 
Moles, A. T., Wallis, I. R., Foley, W. J., Warton, D. I., Stegen, J. C., Bisigato, A. J., Cella-Pizarro, L., Clark, C. J., Cohen, P. S., Cornwell, W. K., Edwards, W., Ejrnaes, R., Gonzales-Ojeda, T., Graae, B. J., Hay, G., Lumbwe, F. C., Magaña-Rodríguez, B., Moore, B. D., Peri, P. L., ... Prior, L. D. (2011). Putting plant resistance traits on the map: A test of the idea that plants are better defended at lower latitudes. New Phytologist, 191(3), 777-788. https://doi. org/10.1111/j.1469-8137.2011.03732.x

Moreira, X., Abdala-Roberts, L., Parra-Tabla, V., \& Mooney, K. A. (2015) Latitudinal variation in herbivory: Influences of climatic drivers, herbivore identity and natural enemies. Oikos, 124(11), 1444-1452. https://doi.org/10.1111/oik.02040

Moreira, X., Abdala-Roberts, L., Rasmann, S., Castagneyrol, B., \& Mooney, K. A. (2016). Plant diversity effects on insect herbivores and their natural enemies: Current thinking, recent findings, and future directions. Current Opinion in Insect Science, 14, 1-7. https://doi. org/10.1016/j.cois.2015.10.003

Moreira, X., Castagneyrol, B., Abdala-Roberts, L., Berny-Mier y Teran, J. C., Timmermans, B. G. H., Bruun, H. H., Covelo, F., Glauser, G., Rasmann, S., \& Tack, A. J. M. (2018). Latitudinal variation in plant chemical defences drives latitudinal patterns of leaf herbivory. Ecography, 41(7), 1124-1134. https://doi.org/10.1111/ecog.03326

Moreira, X., Mooney, K. A., Rasmann, S., Petry, W. K., Carrillo-Gavilán, A., Zas, R., \& Sampedro, L. (2014). Trade-offs between constitutive and induced defences drive geographical and climatic clines in pine chemical defences. Ecology Letters, 17(5), 537-546. https://doi. org/10.1111/ele.12253

Moreira, X., Petry, W. K., Mooney, K. A., Rasmann, S., \& AbdalaRoberts, L. (2018). Elevational gradients in plant defences and insect herbivory: Recent advances in the field and prospects for future research. Ecography, 41(9), 1485-1496. https://doi. org/10.1111/ecog.03184

Murcia, C. (1995). Edge effects in fragmented forests: Implications for conservation. Trends in Ecology and Evolution, 10(2), 58-62. https:// doi.org/10.1016/S0169-5347(00)88977-6

Nakagawa, S., \& Schielzeth, H. (2013). A general and simple method for obtaining $\mathrm{R}^{2}$ from generalized linear mixed-effects models. Methods in Ecology and Evolution, 4(2), 133-142. https://doi. org/10.1111/j.2041-210x.2012.00261.x

Niinemets, Ü. (1997). Role of foliar nitrogen in light harvesting and shade tolerance of four temperate deciduous woody species. Functional Ecology, 11(4), 518-531. https://doi.org/10.1046/j.1365-2435.1997.00109.x

Packham, J. R. (1978). Biological flora of British Isles. Journal of Ecology, 66(2), 669-693.

Pellissier, L., Moreira, X., Danner, H., Serrano, M., Salamin, N., van Dam, N. M., \& Rasmann, S. (2016). The simultaneous inducibility of phytochemicals related to plant direct and indirect defences against herbivores is stronger at low elevation. Journal of Ecology, 104(4), 1116-1125. https://doi.org/10.1111/1365-2745.12580

Pennings, S. C., Ho, C. K., Salgado, C. S., Wieski, K., Davé, N., Kunza, A. E., \& Wason, E. L. (2009). Latitudinal variation in herbivore pressure in Atlantic Coast salt marshes. Ecology, 90(1), 183-195. https://doi. org/10.1890/08-0222.1

Quinn, G. P., \& Keough, M. J. (2002). Experimental design and data analysis for biologists. Cambridge University Press.

R Core Team (2019). A language and environment for statistical computing. R Foundation for Statistical Computing. https://www.R-project.org/

Rahman, M. S., \& Rutter, A. J. (1980). A comparison of the ecology of Deschampsia Cespitosa and Dactylis Glomerata in relation to the water factor: II. Controlled experiments in glasshouse conditions. The Journal of Ecology, 68(2), 479-491. https://doi.org/10.2307/2259417

Rasmann, S., \& Agrawal, A. A. (2011). Latitudinal patterns in plant defense: Evolution of cardenolides, their toxicity and induction following herbivory. Ecology Letters, 14(5), 476-483. https://doi. org/10.1111/j.1461-0248.2011.01609.x

Rasmann, S., Pellissier, L., Defossez, E., Jactel, H., \& Kunstler, G. (2014). Climate-driven change in plant-insect interactions along elevation gradients. Functional Ecology, 28(1), 46-54. https://doi. org/10.1111/1365-2435.12135

Reese, A. T., Ames, G. M., \& Wright, J. P. (2016). Variation in plant response to herbivory underscored by functional traits. PLoS ONE, 11(12), 1-14. https://doi.org/10.1371/journal.pone.0166714

Remy, E., Wuyts, K., Boeckx, P., Ginzburg, S., Gundersen, P., Demey, A., Van Den Bulcke, J., Van Acker, J., \& Verheyen, K. (2016). Strong gradients in nitrogen and carbon stocks at temperate forest edges. Forest Ecology and Management, 376(2016), 45-58. https://doi. org/10.1016/j.foreco.2016.05.040

Ruiz, N., Ward, D., \& Saltz, D. (2002). Calcium oxalate crystals in leaves of Pancratium sickenbergeri: Constitutive or induced defence? Functional Ecology, 16, 99-105. https://doi. org/10.1046/j.0269-8463.2001.00594.x

Salazar, D., \& Marquis, R. J. (2012). Herbivore pressure increases toward the equator. Proceedings of the National Academy of Sciences USA, 109(31), 12616-12620. https://doi.org/10.1073/pnas.12029 07109

Sardans, J., Grau, O., Chen, H. Y. H., Janssens, I. A., Ciais, P., Piao, S., \& Peñuelas, J. (2017). Changes in nutrient concentrations of leaves and roots in response to global change factors. Global Change Biology, 23(9), 3849-3856. https://doi.org/10.1111/gcb.13721

Schemske, D. W., Mittelbach, G. G., Cornell, H. V., Sobel, J. M., \& Roy, K. (2009). Is there a latitudinal gradient in the importance of biotic interactions? Annual Review of Ecology, Evolution, and Systematics, 40(1), 245-269. https://doi.org/10.1146/annurev.ecols ys.39.110707.173430

Verheyen, K., Honnay, O., Motzkin, G., Hermy, M., \& Foster, D. R. (2003). Response of forest plant species to landuse change. Journal of Ecology, 91, 563-577. https://doi. org/10.1046/j.1365-2745.2003.00789.x

Woodman, R. L., \& Fernandes, G. W. (1991). Differential mechanical defense: Herbivory, evapotranspiration, and leaf-hairs. Oikos, 60(1), 11-19. https://doi.org/10.2307/3544986

\section{BIOSKETCH}

Pieter Sanczuk is a PhD student interested in the modulating role of forest microclimate on understorey plant responses to macroclimate warming. His research frames within the FORMICA research project (http://www.formica.ugent.be/).

\section{SUPPORTING INFORMATION}

Additional supporting information may be found online in the Supporting Information section.

How to cite this article: Sanczuk P, Govaert S, Meeussen C, et al. Small scale environmental variation modulates plant defence syndromes of understorey plants in deciduous forests of Europe. Global Ecol Biogeogr. 2020;00:1-15. https://doi.org/10.1111/geb.13216 